\title{
Determining the influencing factors of preferential flow in ground fissures for coal mine dump eco-engineering
}

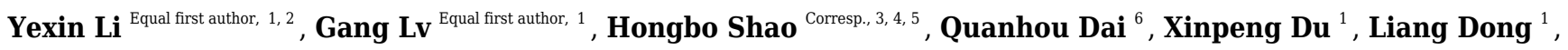 \\ Shaoping Kuang ${ }^{5}$, Daohan Wang ${ }^{\text {Corresp. } 1}$ \\ ${ }^{1}$ College of Environmental Science and Engineering, Liaoning Technical University, Fuxin, P.R.China \\ ${ }^{2}$ School of Architecture and Civil Engineering, Shenyang University of Technology, Shenyang, P.R.China \\ 3 Salt-Soil Agricultural Center, Key Laboratory of Agricultural Environment in the Lower Reaches of Yangtze River Plain, Institute of Agriculture Resources \\ and Environment, Jiangsu Academy of Agricultural Sciences (JAAS), Nanjing, P.R.China \\ 4 Jiangsu Key Laboratory for Bioresources of Saline Soils, Jiangsu Synthetic Innovation Center for Coastal Bio-agriculture, Yancheng Teachers University, \\ Yancheng, P.R. China \\ 5 College of Environment and Safety Engineering, Qingdao University of Science \& Technology(QUST), Qingdao, P.R. China \\ 6 College of Forestry, Guizhou University, Guiyang, P.R.China
}

Corresponding Authors: Hongbo Shao, Daohan Wang

Email address: shaohongbochu@126.com, wangdaohan@sina.com

Ground fissures (GF), appearing in front of dumps, are one of the most obvious and harmful geological hazards in coal mining areas. Studying preferential flow and its influencing factors in the ground fissures of dumps may provide basic scientific support for understanding the rapid movement of water and vegetation restoration and reconstruction in mining areas. Based on field surveys of ground fissures, three typical ground fissures were selected in the studied dump. The morphological characteristics of preferential flow for ground fissures were determined through field dye tracing, laboratory experiments, and image processing technology. The results indicated that the lengths of the three ground fissures ranged from $104.84 \mathrm{~cm}$ and $120.83 \mathrm{~cm}$, and the widths ranged from 2.86 $\mathrm{cm}$ to $9.85 \mathrm{~cm}$. All of the ground fissure area densities were less than $10 \%$, and the proportion of ground fissure surface area was small in the dump. The maximum fissure depth was $47 \mathrm{~cm}$, and the minimum was $16 \mathrm{~cm}$. The ground fissure widths ranged from 0 to $14.98 \mathrm{~cm}$, and the fissure width and fissure width-to-depth ratios decreased with increasing soil depth. The stained area was greater than $90 \%$ in the $0-5 \mathrm{~cm}$ soil layers of the three fissures, and water movement was dominated by matrix flow. The stained width decreased from $90 \mathrm{~cm}$ to $20 \mathrm{~cm}$ with increasing soil depth. The preferential flow was mainly concentrated on both sides of the fissure, which was distributed as a " $\mathrm{T}$ " shape. The preferential flow stained area ratios were $27.23 \%, 31.97 \%$, and $30.73 \%$, respectively, and these values decreased with increasing soil depth. The maximum stained depths of the preferential flow among the three fissures were different, and the maximum stained depth of GF II was significantly larger than that of GF I and GF III $(P<0.05)$. The stained 
path numbers of the three fissures ranged from 0 to 49. With increasing soil depth, the stained path number first increased and then decreased. The stained path widths of the three fissures ranged from 0 to $90 \mathrm{~cm}$. With the increase in soil depth, the stained path width decreased. The stained area ratio was significantly positively correlated with ground fissure width, the ground fissure width-to-depth ratio, soil saturated hydraulic conductivity, soil organic matter, and sand content and was significantly negatively correlated with soil water content and clay content. The stained path number was significantly positively correlated with ground fissure width, the ground fissure width-to-depth ratio, soil saturated hydraulic conductivity and soil organic matter. The stained path width was significantly positively correlated with the ground fissure width-to-depth ratio, soil saturated hydraulic conductivity, soil organic matter and sand content and was significantly negatively correlated with clay content. Plant roots could significantly increase the stained area ratio, stained path number, and width and promote the formation and development of preferential flow. 
1 Determining the influencing factors of preferential flow in ground fissures for

\section{coal mine dump eco-engineering}

Yexin $\mathrm{Li}^{1,2 \dagger}$, Gang Lv ${ }^{1 \dagger}$, Hongbo Shao ${ }^{3,4,5^{*}}$, Quanhou Dai ${ }^{6}$, Xinpeng Du ${ }^{1}$, Liang Dong ${ }^{1}$, Shaoping Kuang 5 , Daohan Wang ${ }^{1 *}$

${ }^{1}$ College of Environmental Science and Engineering, Liaoning Technical University, Fuxin, P.R.China

2 School of Architecture and Civil Engineering, Shenyang University of Technology, Shenyang, P.R.China

${ }^{3}$ Salt-Soil Agricultural Center, Key Laboratory of Agricultural Environment in the Lower Reaches of Yangtze River Plain, Institute of Agriculture Resources and Environment, Jiangsu Academy of Agricultural Sciences (JAAS), Nanjing, P.R.China

4 Jiangsu Key Laboratory for Bioresources of Saline Soils, Jiangsu Synthetic Innovation Center for Coastal Bio-agriculture, Yancheng Teachers University, Yancheng, P.R. China

5 College of Environment and Safety Engineering, Qingdao University of Science \& Technology(QUST), Qingdao, P.R. China

${ }^{6}$ College of Forestry, Guizhou University, Guiyang, P.R.China

†Yexin Li and Gang Lv contributed equally to this work.

\section{* Corresponding authors at}

Prof. Dr.Hongbo Shao, Salt-soil Agricultural Center, Institute of Agricultural Resources and Environment, Jiangsu Academy of Agricultural Sciences(JAAS),Zhongling Street 50, Nanjing 210014, P.R.China.E-mail:shaohongbochu@126.com (HB.SHAO).

Prof. Dr.Daohan Wang, College of Environmental Science and Engineering, Liaoning Technical University, No. 47, Zhonghua Rd, Fuxin, 123000, P.R. China. E-mail: wangdaohan@sina.com (DH. WANG). 
Ground fissures (GF), appearing in front of dumps, are one of the most obvious and harmful geological hazards in coal mining areas. Studying preferential flow and its influencing factors in the ground fissures of dumps may provide basic scientific support for understanding the rapid movement of water and vegetation restoration and reconstruction in mining areas. Based on field surveys of ground fissures, three typical ground fissures were selected in the studied dump. The morphological characteristics of preferential flow for ground fissures were determined through field dye tracing, laboratory experiments, and image processing technology. The results indicated that the lengths of the three ground fissures ranged from $104.84 \mathrm{~cm}$ and $120.83 \mathrm{~cm}$, and the widths ranged from $2.86 \mathrm{~cm}$ to 9.85

$\mathrm{cm}$. All of the ground fissure area densities were less than $10 \%$, and the proportion of ground fissure surface area was small in the dump. The maximum fissure depth was $47 \mathrm{~cm}$, fissure width and fissure width-to-depth ratios decreased with increasing soil depth. The stained area was greater than $90 \%$ in the $0-5 \mathrm{~cm}$ soil layers of the three fissures, and water were $27.23 \%, 31.97 \%$, and $30.73 \%$, respectively, and these values decreased with increasing soil depth. The maximum stained depths of the preferential flow among the three fissures 
47 were different, and the maximum stained depth of GF II was significantly larger than that of

48 GF I and GF III $(\mathrm{P}<0.05)$. The stained path numbers of the three fissures ranged from 0 to

49 49. With increasing soil depth, the stained path number first increased and then decreased.

50 The stained path widths of the three fissures ranged from 0 to $90 \mathrm{~cm}$. With the increase in

51 soil depth, the stained path width decreased. The stained area ratio was significantly

52 positively correlated with ground fissure width, the ground fissure width-to-depth ratio, soil

53 saturated hydraulic conductivity, soil organic matter, and sand content and was significantly

54 negatively correlated with soil water content and clay content. The stained path number was

55 significantly positively correlated with ground fissure width, the ground fissure width-to-

56 depth ratio, soil saturated hydraulic conductivity and soil organic matter. The stained path

57 width was significantly positively correlated with the ground fissure width-to-depth ratio,

58 soil saturated hydraulic conductivity, soil organic matter and sand content and was

59 significantly negatively correlated with clay content. Plant roots could significantly increase

60 the stained area ratio, stained path number, and width and promote the formation and

61 development of preferential flow.

62 KEYWORDS: Preferential flow; Ecoengineering dump; Dye tracer; Ground fissures; Roots

\section{Introduction}

Global climate change can lead to frequent regional droughts and floods and uneven distributions of precipitation and water resources. Global climate change can also gradually increase the frequency and intensity of extreme weather events, causing serious damage to agricultural

67 production. With the occurrence of droughts, soil moisture decreases continuously under 
evaporation and dry conditions, resulting in different degrees of cracks in the earth and ground fissures (Gaur et al., 2015; Ren et al., 2016). Ground fissures are affected by different factors, such as soil texture (Grey and Allbrook, 2002), soil organic carbon (Kechavarzi et al., 2010), alternating soil drying and wetting (Zhang et al., 2013), freeze and thaw action (Maloof et al., 2002), and tillage methods (Bandyopadhyay et al., 2003; Zhang et al., 2016b). The formation of ground fissures not only changes the soil structure (Bruand et al., 2001) and increases the infiltration path and capacity of surface runoff (Liu et al., 2003) but also affects the growth, development, and ecohydrological processes of vegetation, leading to land degradation. Land degradation is a global problem that has attracted substantial attention from scholars (GarcíaGonzález et al., 2018; Nabiollahi et al, 2018; Shao et al., 2018; Zika and Erb, 2009).

Preferential flow is defined as a phenomenon in which soil water moves along certain pathways, such as soil macropores, soil cracks, wormholes, and plant roots, bypassing most of the porous matrix and quickly moving through the soil media (Bero et al., 2016; Hagedorn and Bundt, 2002; Hardie et al., 2011; Rye and Smettem, 2017). Soil preferential flow is caused by the spatial heterogeneity of the soil structure, which exists in the process of soil water infiltration (Clothier et al., 2008). Surroundings and imbalance are two important features of preferential flow (Zhang et al., 2016a). The soil hydrological process, with preferential flow as one of the factors influencing environmental issues, specifically land degradation and groundwater resource security, occurs throughout the world and has been studied at different scales from the field plot and hillslope scale to the catchment scale (Keesstra et al., 2016; Zehe et al., 2010). At present, many experts and scholars mainly focus on soil preferential flow characteristics and their 
89 influencing factors under different land uses (Allaire et al., 2009; Clark and Zipper, 2016; Laine-

90 Kaulio et al., 2015; Leuther et al., 2018). Berli et al. (2004) carried out a study on agricultural

91 and forest soils and found that soil with different compaction degrees has different preferential

92 flow characteristics. Li and Ghodrati (1994) concluded that plant roots were the key factor

93 affecting the preferential flow of forest soil. Liu and Du (2013) investigated the characteristics of

94 soil preferential flows in different vertical traps in mountains along the Dalaoling-Dengcun section of the Three Gorges of the Yangtze River. The preferential flow paths in deserted farmland differ from those in forest soils, and the water infiltration intensity was low and the colour of the stained area was light. Wu et al. (2014) investigated and quantified the preferential flow in five intact and five disturbed soil columns sampled by a Brilliant Blue FCF dye tracer experiment and noted that preferential flow developed in the intact soil columns, while piston flow developed in the disturbed soil columns. Preferential flow may accelerate or delay the movement of matter depending upon the position of the matter compared to the position of preferential flow paths. Four types of preferential flow can be considered: crack flow, finger flow, lateral flow and macropore flow (Allaire et al., 2009; Zhang and Peng, 2015).

Mine spoils are an important driver of environmental damage and land degradation, causing the disappearance of soil and vegetation; increases in erosion by wind and water; pollution of air, soil, and water; and general deterioration of the landscape (Mukaro et al., 2017). Coal mining will result in different degrees of surface damage and deformation, causing ground fissures (Yang et al., 2018; Zhang et al., 2015). Ground fissures have no obvious frame structure. The numbers of fissures, fissure blocks, and nodes are relatively small. The depths of the fissures are 
110 also different. Ground fissures have relatively strong spatial variability yet clear self-similarity

111 (Díaz-Fernández et al., 2010; Li et al., 2018). These factors lead to different preferential flows

112 (Guo et al., 2018). Cheng (2016) determined that the preferential flow of fissures was a direct

113 factor in the change in the soil environment in a mining area and a driving factor of soil erosion

114 in a mining area, and soil crevice preferential flow provides a preferential path for water to

115 transport soil particles from the surface layer to the deep layer, and crevices with soil particles

116 filled will become long-term preferential flow paths. Yan et al. (2018) carried out a study on

117 ammonia concentration and particle size change in soil during the rainfall-runoff process and

118 found that ground fissures with uneven settlement not only changed the surface topographic

119 gradient and soil structure significantly but also aggravated the transport intensity of nutrients

120 and particles in soil with runoff in the horizontal direction. Moreover, the authors determined

121 that the soil cracks produced by surface subsidence formed a series of groundwater preferential

122 flow paths and promote nutrient transport towards a deeper layer. Ground fissure preferential

123 flow was the important driving factor for soil erosion. The subsidence area without any

124 vegetation in Shenfu-Dongsheng coalfield has been taken as research area. Two test points were

125 set in a $50 \mathrm{~m} \times 50 \mathrm{~m}$ testing area, then $4 \mathrm{~g} / \mathrm{L}$ bright-blue solution was used to dye it, and images

126 were taken in 1 horizontal and 5 vertical sections, and the characteristic of preferential flow in

127 the soil cracks of a coal mining subsidence area ( Guo et al., 2018). In addition, soil cracks

128 accelerate water infiltration into deep soil along cracks, reduce soil shear strength, raise

129 groundwater levels, and induce natural disasters such as landslides and debris flows (Krzeminska

130 et al., 2012; Kukemilks et al., 2017; Ma, 2007; Woerden, 2014). Reclaimed mine soil is an 
131 important manifestation of land degradation, which is caused by vegetation degradation, pressure

132 station land and serious soil erosion. Therefore, understanding the land degradation response to

133 preferential flow is essential.

134 In summary, studies of soil fissures in coal mining areas are mostly concentrated in subsidence

135 areas, while few studies have focused on ground fissures in dump areas, such as Zhou (2011),

136 Wang (2012). Zhou et al (2011) pointed out that rainfall and groundwater discharge was

137 important factors for the formation and development of ground fissure. Wang et al (2012) carried

138 out that ground fissure were the precursor of landslide or debris flow hazard in the dump area.

139 Moreover, the study of preferential flow in ground fissures is still lacking, especially in surface

140 coal mine dumps. Ground fissure will change the surface runoff movement, causing a large

141 amount of water to move to the deep soil in the dump area, which is easy to induce disasters,

142 such as landslide and debris flow. A comprehensive understanding of the characteristics of

143 preferential flow in the ground fissures of a dump is of great scientific significance for

144 understanding water and soil loss and for implementing vegetation restoration in mining areas.

145 The aims of this study were to 1) reveal the characteristics of the preferential flow of ground

146 fissures and 2) clarify the influencing factors of soil preferential flow. The research results could

147 provide a scientific basis for understanding the rapid movement of water, vegetation restoration,

148 and eco-engineering in mining areas. 


\section{2. Methods and materials}

\section{$150 \quad 2.1$ Study site}

151 The study area is in the south dump of Shenglidong Open-pit Coal Mine No. 2 of Datang

152 International Power Generation Company in Xilinhot city, Xilingol league, Inner Mongolia (Fig.

153 1). The study area is located at $116^{\circ} 06^{\prime} 41^{\prime \prime}$ to $116^{\circ} 14^{\prime} 11^{\prime \prime} \mathrm{E}$ and $44^{\circ} 02^{\prime} 0^{\prime \prime}$ to $44^{\circ} 07^{\prime} 05^{\prime \prime} \mathrm{N}$ in the

154 southeastern part of the mining area. The total area is $13.66 \mathrm{~km}^{2}$. The local climate is arid and

155 semiarid in the middle temperate zone. The average annual temperature is $1.7^{\circ} \mathrm{C}$, and the average

156

157

158

159

160

161

162

163

164

165

166

167

168

annual precipitation is $284.74 \mathrm{~mm}$. Precipitation mainly occurs in June-August, accounting for more than $71 \%$ of the annual rainfall. Heavy rainfall usually and frequently occurs in these three months, especially between mid-July and mid-August. The long-term mean maximum precipitation in 24 hours is $46.8 \mathrm{~mm}$. The annual average evaporation is $1794.6 \mathrm{~mm}$, and the annual average wind speed is $3.4 \mathrm{~m} \mathrm{~s}^{-1}$. The freezing period is from early October to early December, while the thawing period is from late March to the middle of April. The maximum depth of frozen soil is $2.89 \mathrm{~m}$, and the soil is typical chestnut soil. The climate conditions are mainly derived from China Meteorological science data sharing service platform, with an average value of 30 years. One dump is located to the south of the first mining zone and within the mining area; that is, the south and north dumps are set to the south and north of the first mining zone of the mining site, respectively. The service life of each dump is 20 years. The main design parameters of the south dump are shown in Table 1. To restore the vegetation of the dump as soon as possible, soil covering measures were applied for the platform and slope reclamation 
169 (the soil is sandy loam). The thickness of the covering soil on the platform is approximately $1 \mathrm{~m}$

170 and that over the slope is approximately $0.5 \mathrm{~m}$. The vegetation for the reclamation is shrubs or

171 herbage, such as Caragana korshinskii Kom., Hippophae rhamnoides Linn., Astragalus

172 adsurgens Pall., Melilotus suaveolens Ledeb., and Medicago Sativa Linn.

1732.2 Research methods

174 2.2.1 Sample selection and layout

175 Relevant studies show that the subsidence coefficient of a dump generally ranges between 1.1

176 and 1.2. The subsiding process lasts for several years, but the subsidence in the first three years

177 can account for $80 \%$ of the total subsidence (Han et al., 2011). In this study, Platform 1105 was

178 taken as the research object. Soil covering was performed on Platform 1105 in 2013 after the

179 platform was fully dumped (4 years dumping time). In August 2017, the distribution

180 characteristics and development degree of the ground fissures on the platform were fully

181 examined. According to the investigation, there were 61 ground fissures with different sizes on

182 Platform 1105. The fissures stretched along the contour lines (the margins of the dump). Straight

183 lines were the dominant form of the fissures. The fissures were concentrated within the first $5 \mathrm{~m}$

184 from the frontal edge of the dump. The surface parts of some fissures had cut through the

185 platform and became interwoven with each other, forming a fissure zone. In fissure zones and

186 areas with extensively developed ground fissures, collapse and breakoff often occur at the edges

187 of fissures. All the ground fissure were divided into several groups according to their width, and

188 perform mathematical statistical analysis to screen out the 3 groups with the highest frequency,

189 and a typical ground fissure was selected in each group. Three typical fissures, which were 
190

191

192

193

194

195

196

197

198

199

200

201

202

203

204

205

206

207

208

209

210

marked GF I, GF II, and GF III, were selected as the study objects by statistical analysis. The horizontal morphological characteristics of the ground fissures were investigated by using “frame photography" methods (Han et al., 2011; Kishné et al., 2010). At the same time, three soil profiles $(30 \mathrm{~cm}, 50 \mathrm{~cm}$ and $70 \mathrm{~cm}$ in the sample plot) were excavated in each sample plot to obtain the vertical distribution map of ground fissures. ArcGIS 10.5 and AutoCAD 2008 software were used to digitalize the photographs of the ground fissures and obtain the horizontal and vertical morphological characteristics. The fissure length is the length of the centerline of a fissure. The fissure width is the surface width of a fissure. The fissure depth is the vertical depth of a fissure. The fissure perimeter is the total length of the outline of a fissure, and the fissure area is the area within the outline of a fissure. The fissure length density is the ratio between the fissure length and sample square $(100 \mathrm{~cm} \times 100 \mathrm{~cm})$. The fissure area density is the ratio between the fissure area and sample square $(100 \mathrm{~cm} \times 100 \mathrm{~cm})$. The fissure width-to-depth ratio is the ratio between fissure width and fissure depth.

\subsubsection{Dye-staining experiment and sample collection}

In each experimental plot, four iron plates were embedded into the soil. The length and width of the iron plate were $105 \mathrm{~cm}$ and $50 \mathrm{~cm}$, respectively. The rectangular iron frame was elevated 45 $\mathrm{cm}$ above the soil surface and $5 \mathrm{~cm}$ under the soil surface. To improve the test accuracy, the soil within $5 \mathrm{~cm}$ of the inside frame could be compacted. According to previous research results, preferential flow mostly occurred under heavy rainfall conditions. It was calculated that $50 \mathrm{~L}$ bright blue solution was needed for one test based on the size of the sample plot $(105 \mathrm{~cm} \times 105$ $\mathrm{cm}$ ) in terms of actual consumption and loss. The rainfall intensity at this time was $50 \mathrm{~mm} \mathrm{~h}^{-1}$. 
211 Brilliant Blue FCF dye was used in this study due to its good visibility in soils, low toxicity, low 212 sorption, and transport properties similar to water (Germán-Heins and Flury, 2000). In each plot,

$21350 \mathrm{~L}$ of the aqueous solution of Brilliant Blue FCF (concentration=4 $\mathrm{g} \mathrm{L}^{-1}$ ) was applied over $1 \mathrm{~h}$ 214 in the plot at a constant rate of $50 \mathrm{~mm} \mathrm{~h}^{-1}$ using a rainfall simulator, and then, a plastic cloth was 215 placed around the iron plates to prevent water evaporation. The canvas was removed $24 \mathrm{~h}$ into 216 the dye-staining experiment, and the section perpendicular to the ground fissure was selected as 217 the observation surface of the dyeing test. Three soil profiles were laid at 30,50 and $70 \mathrm{~cm}$. The 218 size was determined by placing the pole on the surface of the section in the form of a square. 219 Then, a vertical acquisition dyeing profile was obtained using a digital camera with 12 million pixels after dressing the soil profile, and 3-5 photos were selected for the next picture process (Fig. 2). Stained images were collected at the same time, usually at $11 \mathrm{am}$. We can ensure that all tasks were completed before 11 am, except for stained image collection. At the same time, use PVC panels to block sunlight while taking pictures to avoid shadows. At the same time, along the vertical direction of the fissure, soil samples were measured at $10 \mathrm{~cm}$ intervals at a depth of 0-60 $\mathrm{cm}$ by a ring knife ( $5 \mathrm{~cm}$ high, $200 \mathrm{~cm}^{3}$ volume). The soil water content was measured using the drying method, and the soil bulk density, porosity (total porosity, capillary porosity, and non-capillary porosity), and saturated hydraulic conductivity were measured using the ring method (Shi et al., 2016). Then, $2 \mathrm{~kg}$ of soil sample was collected in each soil layer and taken to the laboratory for further analysis. The soil organic matter was measured using the potassium dichromate-external heating method. The soil mechanical composition was measured by the pipette method, and soil texture classification was carried out according to international 
232 classifications [FAO and USDA] (Institute of Soil Science of Chinese Academy of Sciences,

233 1978). All experiments were replicated three times. The roots were collected by using a root

234 drilling method $(10 \mathrm{~cm}$ diameter and $10 \mathrm{~cm}$ length) in each plot, and the sampling depth was the

235 same as that of the soil samples. The root samples were washed from root drilling in the

236 laboratory. The root length, surface area and volume were determined using WinRHIZO PRO

2372009 software. The root biomass was weighed after being oven-dried at $75^{\circ} \mathrm{C}$.

$238 \quad 2.2 .3$ Image processing

239 Four steps were necessary to obtain stained image characteristics, such as the stained area ratio,

240 maximum stained depth, stained path number, and width. The first step was to correct the

241 pictures of certain profiles that could not be photographed orthogonally by ERDAS IMAUINE

2429.2 software and output JPG files of the RGB format with a size of 900x700 pixels. The second

243 step was to adjust the new correct image using the image editing program Adobe Photoshop CS6.

244 The third step was to convert the image from RGB format to greyscale images, denoise the

245 image using Image-Pro Plus 6.0 software, and then output the TIFF files. One pixel represented

246 an area of $1 \mathrm{~mm} \times 1 \mathrm{~mm}$ in the true coordinate system. The stained areas turned black, while the

247 remaining areas stayed white. A " 0 " was the expression of black, while " 225 " was the expression

248 of white. The fourth step was to draw a numerical matrix of the bitmap with a $900 \times 700$

249 resolution and save it as an Excel file.

$250 \quad$ 2.2.4 Index of soil preferential flow

251 (1) Maximum stained depth

252 The maximum stained depth is the maximum stained depth of preferential flow in the soil profile, 
253 and this depth can most directly reflect the characteristics of rapid water movement and

254 migration depth.

255 (2) Stained path number and stained path width

256 The stained path number and width can reflect the connectivity, interaction and variability in 257 preferential flow paths. The number of continuous black grids in each layer $(1 \mathrm{~cm})$ is calculated 258 and recorded as a stained path. The number of stained paths in each layer is counted, and the 259 actual width of the stained path is obtained by multiplying the proportion of one stained path by 260 the actual width.

261 (3) Stained area ratio and its coefficient of variation

262 The stained area ratio is the proportion of preferential flow stained area in a soil profile area, which is derived from stained pixels and unstained pixels in a soil profile. It not only reflects the proportion of stained area, but also reflects the distribution characteristics of soil preferential flow and its changes with soil depth. The stained area ratio has different characteristics because of the different width and depth of the ground fissures. It can be calculated from Eq. (1):

$$
K=\frac{P}{P+Q} \times 100 \%
$$

where $K$ is the stained area ratio (\%), $P$ is the stained pixels in the soil profile $\left(\mathrm{cm}^{2}\right)$, and $Q$ is the unstained pixels in the soil profile $\left(\mathrm{cm}^{2}\right)$.

The coefficient of variation of the stained area ratio can directly reflect the changes in the stained area at different depths of the soil profile. The smaller the coefficient is, the higher the degree of

272 development of soil preferential flow. The coefficient of variation can be calculated from Eq. (2): 


$$
C_{V}=\frac{S}{x} \times 100 \%=\frac{\sqrt{\frac{1}{n-1} \sum_{i=1}^{n}\left(x_{i}-x\right)^{2}}}{\frac{1}{n} \sum_{i=1}^{n} x_{i}} \times 100 \%
$$

274 where $C_{v}$ is the coefficient of variation of the stained area ratio (\%), $S$ is the standard deviation of

275 the stained area ratio $(\%), x$ is the average of the stained area ratio $(\%), x_{i}$ is the stained area ratio 276 at $i \mathrm{~cm}$ of soil profile (\%), and $n$ is the equipartition number of the stained image (each size is 1

$277 \mathrm{~cm})$.

278

\subsubsection{Data analysis}

279 Statistical data analysis was performed using Microsoft Excel 2003 and SPSS Statistics 17.0 software. The mean, standard deviation and coefficient of variation were calculated by Microsoft

Excel 2003. Drawing was performed using Origin 8.0 software. Image processing was performed using ERDAS IMAUINE 9.2 software, Adobe Photoshop CS6 and Image-Pro plus 6.0 software. The least significant difference (LSD) method was used for multiple comparisons by SPSS Statistics 17.0 software. The LSD test uses the square root of the residual mean square from the one-way analysis of variance (ANOVA) and considers it to be the pooled significant difference.

\section{Results}

\subsection{Characteristics of ground fissures in the studied dump}

Table 2 shows the morphological characteristics of ground fissures in the studied dump. The lengths of the three ground fissures ranged from $104.84 \mathrm{~cm}$ and $120.83 \mathrm{~cm}$, and all larger were than $100 \mathrm{~cm}$ (the side length of the sample square), indicating that the fissures had different degrees of curvature. Fissure width reflects the degree of opening and fissure disturbance to soil 
292

293

294

295

296

297

298

299

300

301

302

304

305

306

continuity. The ground fissure widths of GF I, GF II, and GF III were $9.85 \mathrm{~cm}, 2.86 \mathrm{~cm}$, and 5.77 $\mathrm{cm}$, respectively. There were significant differences among the three fissures $(\mathrm{P}<0.05)$. Of the fissures, GF I had the greatest degree of opening and caused the most disturbance to soil continuity. The ground fissure area densities of GF I, GF II, and GF III were 9.84\%, 2.86\%, and 5.76\%, respectively. There were significant differences among the three fissures $(\mathrm{P}<0.05)$. All were less than $10 \%$, which showed that the proportion of ground fissure surface area was small in the dump.

The vertical distribution of a ground fissure reflects the variation in fissure width with soil depth. As shown in Fig. 3, the ground fissure depths of GF I, GF II, and GF III were $29 \mathrm{~cm}, 30.67 \mathrm{~cm}$, and $28.67 \mathrm{~cm}$, respectively. There was no significant difference among the three ground fissures $(\mathrm{P}>0.05)$. The maximum fissure depth of GF III was $47 \mathrm{~cm}$, and the minimum fissure depth was $16 \mathrm{~cm}$. A ground fissure has obvious spatial variability. The ground fissure width decreased with increasing soil depth. The fissure width of GF I ranged from 1.8 to $13.77 \mathrm{~cm}$, that of GF II ranged from 0 to $10.58 \mathrm{~cm}$, and that of GF III ranged mainly from 1.12 to $14.98 \mathrm{~cm}$. The maximum fissure width appeared on the surface (soil depth was $0 \mathrm{~cm}$ ), which indicates that disturbance to soil continuity decreased with increasing soil depth. The fissure width of GF I-70 $\mathrm{cm}$ decreased sharply from $8.61 \mathrm{~cm}$ to $1.8 \mathrm{~cm}$ at a depth of $19-22 \mathrm{~cm}$. For GF II, the fissure widths of GF II-30 cm, GF II-50 cm, and GF II-70 cm decreased continuously at depths of 0-5 $\mathrm{cm}$, and then, those of GF II-30 $\mathrm{cm}$ and GF II-50 $\mathrm{cm}$ fluctuated. The fissure width of GF II-70 $\mathrm{cm}$ was 0 at depths of 10-27 $\mathrm{cm}$ because the fissures in this position were buried by soil particles. The fissure widths of GF III-30 $\mathrm{cm}$ and GF III-50 cm decreased with increasing soil depth, and 
313 those of GF III-70 cm decreased sharply from $5.07 \mathrm{~cm}$ to $7.84 \mathrm{~cm}$ at $27 \mathrm{~cm}$, showing a

314 decreasing trend.

315 Fig. 4 indicates that as fissure depth increased, the ground fissure width-to-depth ratio

316 significantly decreased. The ground fissure width-to-depth ratio decreased rapidly within the

317 depth range of 0 to $10 \mathrm{~cm}$ and then stabilized. The width-to-depth ratios of different profiles in

318 the same fissure had the same variation tendency, but the maximum width-to-depth ratio was

319 different. The maximum width-to-depth ratios of the three soil profiles with GF I were 4.78,

320 8.97, and 13.77; those of GF II were 8.72, 10.14, and 10.58; and those of GF III were 10.33,

32114.98 , and 5.14. The stability of the width-to-depth ratios was only from $0.43 \%$ to $1.71 \%$ of the

322 maximum value.

3233.2 Characteristics of preferential flow in studied the dump

324 3.2.1 Morphological characteristics of preferential flow

325 Fig. 5 shows the vertical distribution characteristics of preferential flow for the three ground

326 fissures. The stained area was greater than $90 \%$ in the $0-5 \mathrm{~cm}$ soil layer for the three fissures. The

327 stained area was evenly distributed, and preferential flow development was not obvious. Water

328 movement was dominated by matrix flow, which was due to the effect of matrix flow being

329 greater than that of preferential flow. The stained width decreased from $90 \mathrm{~cm}$ to $20 \mathrm{~cm}$ with

330 increasing soil depth. The preferential flow stained area was mainly concentrated on both sides

331 of the fissure and was closely related to the preferential movement of water to the ground fissure.

332 The preferential flow was mainly concentrated in the middle of the stained image, which was

333 distributed as a "T" shape, but there were no significant differences for GF I, GF II and GF III.

Peer] reviewing PDF | (2020:08:51845:2:0:NEW 20 Nov 2020) 
334

335

336

337

338

339

340

341

342

343

344

345

346

347

348

349

350

351

352

353

354

\subsubsection{Stained area ratio}

The stained area ratios of GF I, GF II and GF III were $27.23 \%, 31.97 \%$ and $30.73 \%$, respectively, which decreased with increasing soil depth and were distributed in an "S" shape (Fig. 6). The stained area ratio was the largest in the $0-10 \mathrm{~cm}$ soil layer, and the ratios of GF I, GF III and GF III was $70.97 \%-82.92 \%, 62.51 \%-90.70 \%$ and $70.34 \%-89.06 \%$, respectively. In the $0-10 \mathrm{~cm}$ soil layer, the stained area ratio decreased rapidly. The stained area ratios of GF I, GF II and GF III in the $0-1 \mathrm{~cm}$ soil layer were $99.93 \%, 95.57 \%, 99.98 \%$, respectively, whereas those at $10 \mathrm{~cm}$ were $39.72 \%, 42.13 \%, 42.79 \%$. The stained area ratio decreased with depth; however, this decrease was not linear but fluctuated. When the soil depth was $60-70 \mathrm{~cm}$, the stained area ratio tended to be 0 .

As shown in Fig. 6, the maximum stained depth of the preferential flow among the three fissures was different; the 3 soil profiles for GF I were $50 \mathrm{~cm}, 55.6 \mathrm{~cm}$, and $54.9 \mathrm{~cm}$; those for GF II were $65 \mathrm{~cm}, 63.6 \mathrm{~cm}$, and $59.7 \mathrm{~cm}$; and those for GF III were $56.5 \mathrm{~cm}, 55.6 \mathrm{~cm}$, and $53.9 \mathrm{~cm}$. GF II was significantly larger than GF I and GF III $(\mathrm{P}<0.05)$, and this result was related to the fissure width and depth of GF II. In the $0-70 \mathrm{~cm}$ soil layer, the maximum stained area ratios of the three fissures appeared in the 0-1 cm soil layer, and the values of GF I, GF II, and GF III were 99.93\%, $95.57 \%, 99.98 \%$, respectively. The minimum stained area ratio was 0 , which appeared at $60-70$ cm. For GF I, GF II and GF III, the average values of the stained area ratio were $27.23 \%$, $31.97 \%$, and $30.72 \%$, respectively. The results above showed that the stained area ratio was highly discrete and variable. The coefficient of variation for GF I was $78.95 \%-95.24 \%$, that of GF II was $68.45 \%-77.03 \%$, and that of GF III was $62.92 \%-87.67 \%$. 
355

356

357

358

359

360

361

362

363

364

365

366

367

368

369

370

371

372

373

374

375

\subsubsection{Stained path number and width}

Fig. 7 shows the stained path number and width of three ground fissures. As shown, the stained path number of the three fissures ranged from 0 to 49 . With increasing soil depth, the stained path number first increased and then decreased. The maximum stained path number among the three fissures appeared at different soil depths. For the three soil profiles of GF I, the maximum stained path numbers were 20,36 and 38, which appeared at depths of $8 \mathrm{~cm}, 7 \mathrm{~cm}$ and $6 \mathrm{~cm}$, respectively. For the three soil profiles of GF II, the maximum path numbers were 35, 21 and 18, which appeared at depths of $3 \mathrm{~cm}, 3 \mathrm{~cm}$ and $18 \mathrm{~cm}$, respectively. For the three soil profiles of GF

III, the maximum path numbers were 43, 33 and 49, which appeared at depths of $7 \mathrm{~cm}, 10 \mathrm{~cm}$ and $4 \mathrm{~cm}$, respectively. The maximum stained path numbers of all the soil profiles appeared in the $0-10 \mathrm{~cm}$ soil layer, except that GFII-70 $\mathrm{cm}$ was at $27 \mathrm{~cm}$. This result showed that the water flow morphological differentiation was the most serious in the surface soil. The stained path number decreased below the $10 \mathrm{~cm}$ soil layer, and the value was $0-23$. However, this decrease was not linear but fluctuated. The stained path was mainly concentrated on the area directly below the fissure, which was closely related to the water catchment capacity of the fissure.

Table 3 shows the stained path number and width in different soil layers. With the increase in soil depth, the stained path number of all soil profiles decreased first and then increased, and the maximum appeared in the $0-10 \mathrm{~cm}$ soil layer. However, the stained path number fluctuated greatly at $0-10 \mathrm{~cm}$, with a maximum of 49 and a minimum of 1 . For the stained area with only one stained path, the stained path width was $90 \mathrm{~cm}$ (the stained image width was $90 \mathrm{~cm}$ ), and the stained area covered the whole soil profile. This result showed that this area was a matrix flow 
376

377

378

379

380

381

382

383

384

385

386

area. With the increase in soil depth, the stained path width decreased and was only $9.1-41 \mathrm{~cm}$ in the $10-20 \mathrm{~cm}$ soil layer, accounting for $45.59 \%$ of the $0-10 \mathrm{~cm}$ soil layer. The stained path width of some soil profiles in the 50-60 cm soil layer was 0 , and there was no stained area. In the 60-70 $\mathrm{cm}$ soil layer, only the stained path widths of GF II-30 $\mathrm{cm}$ and GF II -50 cm were not 0 , and the values were $5.2 \mathrm{~cm}$ and $4.8 \mathrm{~cm}$, accounting for $5.78 \%$ and $5.33 \%$ of the stained image width, respectively. The stained area was not obvious, and the preferential flow reached the maximum depth.

\subsection{Influencing factors of soil preferential flow in the studied dump}

\subsubsection{Ground fissure}

As shown in Table 4, the stained area ratio and stained path width were significantly positively correlated with ground fissure width $(\mathrm{P}<0.01)$, and the stained path number was significantly negatively correlated with ground fissure width. The increase in ground fissures significantly increased the stained area ratio and stained path width, providing a preferential channel for water movement. The stained area ratio and stained path width were significantly positively correlated with the ground fissure width-to-depth ratio $(\mathrm{P}<0.01)$, and the stained path number was significantly positively correlated with the ground fissure width-to-depth ratio $(\mathrm{P}<0.05)$. The results above showed that preferential flow morphological characteristics were affected by both ground fissure width and depth. The wider and deeper the ground fissure was, the greater the influence was, and the more obvious the preferential flow development was.

\subsubsection{Soil physiochemical properties}

Table 5 shows the soil physicochemical properties of the ground fissures in the studied dump. 
397 For the three ground fissures, the contents of sand, silt, and clay for the different soil layers were $39858 \%-78.62 \%, 10.25 \%-17.64 \%$ and $6.72 \%-14.63 \%$, respectively, and there was no significant 399 difference between the different soil layers $(\mathrm{P}>0.05)$. The clay content was low, and the soil 400 texture was sandy soil (international classification). Of the soil depths, the $0-10 \mathrm{~cm}$ soil layer had 401 the highest sand content, which decreased with increasing soil depth. The soil water content of 402 all soil profiles ranged from $4.14 \%$ to $7.42 \%$, and the average values in the $0-60 \mathrm{~cm}$ soil layer for 403 the three ground fissures were 5.03\%, 5.02\% and $6.07 \%$. The soil saturated hydraulic 404 conductivity decreased with increasing soil depth. The soil saturated hydraulic conductivity in 405 the $0-10 \mathrm{~cm}$ soil layer was $1.10-1.19 \mathrm{~mm} \mathrm{~min}^{-1}$, and that in the $50-60 \mathrm{~cm}$ soil layer was $0.18-0.42$ $\mathrm{mm} \mathrm{min}^{-1}$, accounting for $15.25-38.18 \%$ of the $0-10 \mathrm{~cm}$ soil layer. For GF I, GF II and GF III, 407 the average values of soil saturated hydraulic conductivity were $0.83 \mathrm{~mm} \mathrm{~min}^{-1}, 0.64 \mathrm{~mm} \mathrm{~min}^{-1}$ and $0.83 \mathrm{~mm} \mathrm{~min}^{-1}$, respectively. Compared to that of GF II, the soil saturated hydraulic conductivities of GF I and GF III were slightly lower; however, there was no significant difference among the three ground fissures $(\mathrm{P}>0.05)$. The soil organic matter decreased first, then increased and then decreased with increasing soil depth, which was distributed as an "S" shape.

412 The soil organic matter in the $0-10 \mathrm{~cm}$ soil layer was the highest because of decomposition and 413 migration of the litter.

414 As shown in Table 6, the stained area ratio was significantly positively correlated with soil 415 saturated hydraulic conductivity $(\mathrm{P}<0.01)$, soil organic matter $(\mathrm{P}<0.05)$ and sand content $(\mathrm{P}<0.05)$ 416 and was significantly negatively correlated with soil water content $(\mathrm{P}<0.05)$ and clay content $417(\mathrm{P}<0.05)$; these results may be because the increase in soil saturated hydraulic conductivity 
418 improved soil hydraulic conductivity, increased the stained area and path of preferential flow, 419 and then promoted the development of preferential flow. The increase in soil organic matter 420 could have promoted soil aggregate formation and improved soil structure and soil infiltration 421 capacity. The stained path number was significantly positively correlated with soil saturated hydraulic conductivity $(\mathrm{P}<0.01)$ and soil organic matter $(\mathrm{P}<0.05)$ and was not significantly correlated with the other indicators $(\mathrm{P}>0.05)$. The stained path width had a significant positive correlation with soil saturated hydraulic conductivity, soil organic matter and sand content $(\mathrm{P}<0.05)$ and a significant negative correlation with clay content $(\mathrm{P}<0.05)$.

426

427

428

\subsubsection{Plant roots}

As shown in Fig. 8, compared to GF I and GF III, the root density of GF II was greater. The root weight densities of the different soil layers of GF I, GF II and GF III were $0.453-0.938 \mathrm{mg} \mathrm{cm}^{-3}$, 0.330-0.914 $\mathrm{mg} \mathrm{cm}^{-3}$, and 0.149-2.69 $\mathrm{mg} \mathrm{cm}^{-3}$, respectively. With increasing soil depth, the root weight density of GF I and GF II first increased and then decreased, while that of GF III decreased. Compared to GF I and GF II, the root weight density of GF III in the 0-10 cm soil layer was $2.69 \mathrm{mg} \mathrm{cm}^{-3}$. The root length density in different soil layers of GF I ranged from $3.242 \mathrm{~cm} \mathrm{~cm}^{-3}$ to $6.243 \mathrm{~cm} \mathrm{~cm}^{-3}$, that of GF II ranged from $3.811 \mathrm{~cm} \mathrm{~cm}^{-3}$ to $7.744 \mathrm{~cm} \mathrm{~cm}^{-3}$, and that of GF III ranged from $3.906 \mathrm{~cm} \mathrm{~cm}^{-3}$ to $6.353 \mathrm{~cm} \mathrm{~cm}^{-3}$. The variation characteristics of root length density for the three fissures were the same as that of root weight density. The root surface area density in different soil layers of GF I ranged from $1.502 \mathrm{~cm}^{2} \mathrm{~cm}^{-3}$ to $2.532 \mathrm{~cm}^{2} \mathrm{~cm}^{-3}$, that of GF II ranged from $1.906 \mathrm{~cm}^{2} \mathrm{~cm}^{-3}$ to $2.647 \mathrm{~cm}^{2} \mathrm{~cm}^{-3}$, and that of GF III ranged from $1.844 \mathrm{~cm}^{2}$ $\mathrm{cm}^{-3}$ to $2.600 \mathrm{~cm}^{2} \mathrm{~cm}^{-3}$. With increasing soil depth, the root surface area density of GF I increased 
439 first and then decreased, while that of GF II and GF III decreased. The root surface area density

440 of the three ground fissures was the highest in the $0-10 \mathrm{~cm}$ or $10-20 \mathrm{~cm}$ soil layer. The root

441 volume density in different soil layers of GF I ranged from $0.056 \mathrm{~cm}^{3} \mathrm{~cm}^{-3}$ to $0.098 \mathrm{~cm}^{3} \mathrm{~cm}^{-3}$,

442 that of GF II ranged from $0.061 \mathrm{~cm}^{3} \mathrm{~cm}^{-3}$ to $0.092 \mathrm{~cm}^{3} \mathrm{~cm}^{-3}$, and that of GF III ranged from 0.063

$443 \mathrm{~cm}^{3} \mathrm{~cm}^{-3}$ to $0.087 \mathrm{~cm}^{3} \mathrm{~cm}^{-3}$. The variation characteristics of root volume density for the three

444 fissures were the same as those of root surface area density.

445 As shown in Table 7, the stained area ratio, stained path number and width were significantly

446 positively correlated with plant roots and could promote the formation and development of

447 preferential flow. The stained area ratio was significantly positively correlated with root length

448 density $(\mathrm{P}<0.01)$, root surface area density $(\mathrm{P}<0.01)$ and root density $(\mathrm{P}<0.05)$. The stained path

449 number was significantly positively correlated with root length density $(\mathrm{P}<0.05)$ but not with

450 other indicators $(\mathrm{P}>0.05)$. The stained path width was significantly positively correlated with

451 root length density $(\mathrm{P}<0.01)$, root surface area density $(\mathrm{P}<0.01)$, root density $(\mathrm{P}<0.05)$, and root

452 weight density $(\mathrm{P}<0.05)$ and was not significantly correlated with other indicators $(\mathrm{P}>0.05)$.

\section{4. Discussion}

\subsection{Morphological characteristics of ground fissures}

455 Ground fissures formed by natural soils, such as paddy soil, expansive soil and clay, are affected

456 by soil texture (Gray and Allbrook, 2002), soil alternating drying and wetting (Zhang et al., 457 2013), freeze and thaw action (Maloof et al., 2002), and tillage methods (Bandyopadhyay et al., 458 2003). However, the formation and development of ground fissures in a dump is also mainly 
459 affected by the gravity of the soil, uneven subsidence and rainfall characteristics (Li et al., 2018;

460 Zhang et al., 2012; Zhou et al., 2011). Therefore, the formation mechanism of ground fissures in

461 a dump is different from that of natural ground fissures. The morphological characteristics of

462 ground fissures in a dump are also unique, and ground fissures are distributed in front of the

463 platform of a dump; most are linear, arcing and polygonal. Similar conclusions were drawn by

464 Zhou et al. (2011). Ground fissures have no obvious frame structures. The numbers of fissures,

465 fissure blocks, and nodes are relatively small. The depths of the fissures are also different.

466 Ground fissures have relatively strong spatial variability yet clear self-similarity (Díaz-Fernández

467 et al., 2010. Li et al., 2018). Studies have shown that ground fissures are distributed on different

468 dump staircases, stretching along the contour lines. The widths of ground fissures vary, with the

469 largest width reaching $10 \mathrm{~cm}(\mathrm{Hu}$ and $\mathrm{Mu}, 2008)$.

\subsection{Effect of ground fissures on preferential flow}

471 Several important processes, such as infiltration, water storage in depressions, erosion and

472 sedimentation, depend on soil microtopography (Bogner et al., 2012). Ground fissures not only

473 change the soil microtopography and slope of the underlying surface but also destroy the

474 continuity of the soil, thus accelerating the convergence of surface runoff, improving the

475 efficiency of the catchment, and forming a preferential channel for water movement. Whether

476 surface runoff occurs depends on the spray intensity and infiltration capacity. When the spraying

477 intensity is greater than the infiltration capacity of the soil, the accumulated water continuously

478 collects to form surface runoff; after the surface runoff flows into the ground fissures, it quickly

479 moves downwards without being absorbed by the surrounding soil. The surface runoff continues 
480

481

482

483

484

485

486

487

488

489

490

491

492

493

494

495

496

497

498

499

500

to collect and fill in the ground fissures and then pass through the ground fissure, soil on both sides and bottom infiltrates into the soil. The depth of soil preferential flow can be reflected by the depth of soil matrix flow, which is the critical depth when the soil matrix flow turns to soil preferential flow, that is, the depth of the soil layer where the soil preferential flow stained area ratio is more than $80 \%$ (Bargués Tobella et al., 2014.). Bogner et al. (2012) concluded that the top $5 \mathrm{~cm}$ of soil is homogenously stained, indicating the dominance of matrix flow. There were narrow stained objects ranging from $5 \mathrm{~cm}$ to the bottom of the soil profiles. Guo et al. (2018) revealed that ground fissures in coal mining subsidence areas cause preferential flow. The width and number of fissures had a significant influence on the preferential flow in the coal mining subsidence area. The results of this study showed that the stained area of preferential flow was mainly located on both sides of the fissure, and flow morphological characteristics of the preferential flow were "above wide and below narrow". The ground fissure width and width-todepth ratio significantly promoted the development of preferential flow, and then, the development of preferential flow further intensified the expansion of ground fissures.

\subsection{Effect of plant roots on preferential flow}

The promotion of preferential flow by plant roots is a common result of multiple factors. Plant roots not only form a preferential path for soil water movement (Van Noordwijk, 1993; Jiang et al, 2018) and increase soil pore connectivity (Cannavo and Michel, 2013) but also network soil and improve soil structure (Lin et al., 2010). Clark and Zipper (2016) noted that soil preferential flow of a dump is mainly concentrated near plant roots. The stained area ratio of a reclaimed forest was larger than that of reclaimed grasses, and the stained path width of a reclaimed forest 
501

502

504

505

506

507

508

509

510

511

512

513

514

515

516

517

518

519

520

was smaller than that of reclaimed grasses. An increase in plant roots can effectively increase the

stained area and stained path width. In addition, an effective increase in root length will increase

not only root expansion in the horizontal direction but also root extension in the vertical direction.

Root surface area can increase the contact area between roots and soil and form a preferential

pathway channel on the root surface, which promotes the development of soil preferential flow

and accelerates water movement (Bogner et al., 2010; JoRgensen et al., 2002). The denser roots

of the plant, the larger the contact area with the soil. Shao et al (2020) pointed out that fine roots

can significantly promote the formation of preferential soil flow. However, the stained area ratio,

stained path number and width were positively correlated with root volume density but not

significantly $(\mathrm{P}>0.05)$. This was because the root volume was an index of three-dimensional

space, while the stained area ratio, stained path number and width were the indexes of two-

dimensional space, which was the projection of stained area on the plane. Therefore, the root volume density did not play a decisive role in preferential flow.

\section{Conclusions}

5 The three ground fissures had different degrees of curvature, and the fissure width was significantly different $(\mathrm{P}<0.05)$, while the fissure depth was not significantly different. The ground fissure width-to-depth ratio decreased with increasing soil depth and then stabilized.

There was no significant difference in preferential flow values among the three fissures, and the values were distributed as a "T" shape. The stained area was greater than $90 \%$ in the $0-5 \mathrm{~cm}$ soil layer for the three fissures. The stained area was evenly distributed, preferential flow 
521 development was not obvious, and the water movement was dominated by matrix flow. The

522 stained area decreased below the $10 \mathrm{~cm}$ soil layer, and the development degree of preferential

523 flow was obvious and was mainly concentrated on both sides of the fissure. The stained area

524 ratios of GF I, GF II and GF III were 27.23\%, 31.97\%, and 30.73\%, respectively, and these

525 ratios decreased with increasing soil depth and were distributed as an "S" shape. The maximum

526 stained area ratio was $90.70 \%$ in the $0-10 \mathrm{~cm}$ soil layer, and the minimum was $62.51 \%$. The

527 stained depth of GF II was significantly greater than that of GF I and GF III. The spatial

528 variability in the stained area ratios for the three fissures was moderate. With increasing soil

529 depth, the stained path number first increased and then decreased. The stained path width of the

530 surface soil reached $90 \mathrm{~cm}$, and the stained path width decreased with increasing soil depth and

531 then finally trended towards 0 . Soil preferential flow was affected by both fissure width and

532 depth. The stained area ratio, stained path number and width were significantly positively

533 correlated with soil saturated hydraulic conductivity, soil organic matter, sand content and plant

534 roots, and these indicators could promote the formation and development of preferential flow.

\section{Acknowledgments}

536 This study was financially supported by the projects of the National Key Research and 537 Development Program of China (2017YFC1503105) and Excellent Scientist Plan of JAAS, 538 China. 
539

540

541

542

543

544

545

546

547

548

549

550

551

552

553

554

555

556

557

558

559

560

561

562

563

564

\section{References}

Ahirwal J, Maiti SK. 2016. Assessment of soil properties of different land uses generated due to surface coal mining activities in tropical Sal (Shorea robusta ) forest, India. Catena 140:155163.

Allaire SE, Roulier S, Cessna A. J. 2009. Quantifying preferential flow in soils: A review of different techniques. J Hydrology 378: 179-204.

Bandyopadhyay KK, Mohanty M, Painuli DK, Misra AK, Hati KM, Mandal KG, Ghosh PK, Chaudhary RS, Acharya CL. 2003. Influence of tillage practices and nutrient management on crack parameters in a Vertisol of central India. Soil Tillage Res 71: 133-142.

Bargués Tobella A, Reese H, Almaw A. The effect of trees on preferential flow and soil infiltrability in an agroforestry parkland in semiarid Burkina Faso. Water Resources Research 50: 3342-3354.

Berli M, Kulli B, Attinger W, Keller M, Leuenberger J, Flühler H, Springman S, Schulin R. 2004. Compaction of agricultural and forest subsoils by tracked heavy construction machinery. Soil Tillage Res 75: 37-52.

Bero NJ, Ruark MD, Lowery B. 2016. Bromide and chloride tracer application to determine sufficiency of plot size and well depth placement to capture preferential flow and solute leaching. Geoderma, 262, 94-100.

Bogner C, Mirzaei M, Ruy S, Huwe B. 2012. Microtopography, water storage and flow patterns in a fine-textured soil under agricultural use. Hydrol Processes 27: 1797-1806.

Bogner C, Wolf B, Schlather M, Huwe B. 2010. Analysing flow patterns from dye tracer experiments in a forest soil using extreme value statistics. Eur J Soil Sci 59: 103-113.

Bruand A, Cochrane H, Fisher P. 2001. Increase in the bulk density of a grey clay subsoil by infilling of cracks by topsoil. Eur J Soil Sci 52: 37-47.

Cannavo P, Michel J C. 2013. Peat particle size effects on spatial root distribution, and changes on hydraulic and aeration properties. Scientia Hort 151: 11-21. 
565

566

567

568

569

570

571

572

573

574

575

576

577

578

579

580

581

582

583

584

585

586

587

588

589

590

Cheng Fk. 2016. Simulation study on soil crack preferential flow and its impacts on soil and water loss in coal mining subsidence areas. Huainan: Anhui Uni Sci Tech (in Chinese).

Clark EV, Zipper CE. 2016. Vegetation influences near-surface hydrological characteristics on a surface coal mine in eastern USA. Catena 139: 241-249.

Clothier BE, Green SR, Deurer M. 2008. Preferential flow and transport in soil: progress and prognosis. Eur J Soil Sci 59: 2-13.

Díaz-Fernández ME, Álvarez-Fernández MI, Álvarez-Vigil AE. 2010. Computation of influence functions for automatic mining subsidence prediction. Comput Geosci 14: 83-103.

García-González I, Hontoria C, Gabriel JL, Alonso-Ayuso M, Quemada M. 2018.Cover crops to mitigate soil degradation and enhance soil functionality in irrigated land. Geoderma, 322, $81-88$.

Gaur VP , Kar SK, Srivastava M. 2015. Development of Ground Fissures: A Case Study from Southern Parts of Uttar Pradesh, India. J Geol Soc India 86: 671-678.

Germán-Heins, J, Flury, M. 2000. Sorption of brilliant blue FCF in soils affected by pH and ionic strength. Geoderma 97: 87-101.

Gray CW, Allbrook R. 2002. Relationships between shrinkage indices and soil properties in some New Zealand soils. Geoderma 108: 287-299.

Guo QL, Su N, Ding B, Yang YS. 2018. Characteristics of preferential flow in the soil cracks of a coal mining subsidence area. Sci Soil Water Conser16: 112-120 (in Chinese).

Hagedorn F, Bundt M. 2002. The age of preferential flow paths. Geoderma 108: 119-132.

Han J, Bai ZK, Li JC. 2011. Analysis on the platform subsidence about western dump in openunderground combine mining. J Shanxi Agri Uni (Nat Sci Ed) 31: 460-463 (in Chinese).

Hardie MA, Cotching WE, Doyle RB, Holz G, Lisson S, Mattern K. 2011.Effect of antecedent soil moisture on preferential flow in a texture-contrast soil. J Hydrology 398: 191-201.

Hu JF, Mu KL. 2008. A preliminary discussion on the application of geophysical methods to dump in a mine. J Chengdu Uni Tech (Sci Tech Ed) 35: 268-273 (in Chinese). 
Institute of Soil Science of Chinese Academy of Sciences. 1978. Soil Chemical and Physical Analysis. Shanghai: Shanghai Science and Technology Press (in Chinese).

Jiang X J, Liu W, Chen C, Liu J, Yuan ZQ, Jin B, Yu X. 2018.Effects of three morphometric features of roots on soil water flow behavior in three sites in China. Geoderma, 320, 161171.

JoRgensen PR, Hoffmann M, Kistrup JP, Bryde C, Bossi R., Villholth KG. 2002. Preferential flow and pesticide transport in a clay-rich till: Field, laboratory, and modeling analysis. Water Res Res 38: 28-1-28-15.

Kechavarzi C, Dawson Q, Leedsharrison P B. 2010. Physical properties of low-lying agricultural peat soils in England. Geoderma 154:196-202.

Keesstra SD, Pereira P, Novara A, Brevik EC, Azorin-Molina C, Parras Alcántara L, Jordán A, Cerdà A. 2016. Effects of soil management techniques on soil water erosion in apricot orchards. Sci Total Environ 551-552: 357-366.

Kishné AS, Morgan CLS, Ge YF, Miller WL. 2010. Antecedent soil moisture affecting surface cracking of a Vertisol in field conditions. Geoderma 157: 109-117.

Krzeminska DM, Bogaard TA, Van Asch TWJ, Van Beek LPH. 2012. A conceptual model of the hydrological influence of fissures on landslide activity. Hydrol Earth System Sci 16: 1561-1576.

Kukemilks K, Wagner JF, Saks T, Brunner P. 2017. Conceptualization of preferential flow for hillslope stability assessment. Hydrogeology J 26: 439-450.

Laine-Kaulio H, Backnäs S, Koivusalo H, Laurén A. 2015.Dye tracer visualization of flow patterns and pathways in glacial sandy till at a boreal forest hillslope. Geoderma, 259-260, 23-34.

Leuther F, Weller U, Wallach R, Vogel HJ. 2018.Quantitative analysis of wetting front instabilities in soil caused by treated waste water irrigation. Geoderma, 319, 132-141.

Li Y, Ghodrati M. 1994. Preferential transport of nitrate through soil columns containing root channels. Soil Sci Soc America J 58:653. 
618 Li YX, Wang DH, Lv G, Diao LF, Dong L, Du XP. 2018. A review of soil mass cracks 619 characteristics and their eco-environmental effects in coal mining area. Chin J Ecol 37:273620283 (in Chinese).

621 Lin DJ, Zheng ZC, Zhang XZ, Li TX, He SQ, Wen Y, Gan CB. 2010. Characteristic and 622 influencing factors of soil infiltration of different land use patterns. Journal of Soil and 623 Water Conservation 24: 33-36 (in Chinese).

624 Liu CW, Cheng SW, Yu WS, Chen SK. 2003. Water infiltration rate in cracked paddy soil. 625 Geoderma 117:169-181.

626 Liu MX, Du WZ. 2013. To investigate soil preferential flow paths in mountain area using dye tracer. Acta Pedol Sin 50: 871-880 (in Chinese).

Ma J. 2017. Preferential flow and stability analysis method for fissure clay slopes. Wuhan: Wuhan Institute of rock and soil mechanics, Chinese Academy of Sciences, P. R. China (in Chinese).

Maloof AC, Kellogg JB, Anders AM. 2002. Neoproterozoic sand wedges: crack formation in frozen soils under diurnal forcing during a snowball Earth. Earth Planetary Sci Lett 204: 1-

Mukaro E, Nyakudya IW, Jimu L. 2017.Edaphic Conditions, Aboveground Carbon Stocks and 15. Plant Diversity on Nickel Mine Tailings Dump Vegetated with Senegalia polyacantha (Willd.) Seigler \& Ebinger. Land Degrad Develop 28: 1641-1651.

Nabiollahi K, Golmohamadi F, Taghizadeh-Mehrjardi R, Kerry R, Davari M. 2018. Assessing the effects of slope gradient and land use change on soil quality degradation through digital mapping of soil quality indices and soil loss rate. Geoderma, 318, 16-28.

Ren J, Li X, Zhao K, Fu B, Jiang T, 2016. Study of an on-line measurement method for the salt parameters of soda-saline soils based on the texture features of cracks. Geoderma, 263, 6069.

Rye CF, Smettem KRJ. 2017. The effect of water repellent soil surface layers on preferential flow and bare soil evaporation. Geoderma, 289, 142-149. 
645 Shao HB, Chu LY, Lu HY, Qi WC, Chen X, Liu J, Kuang SP, Tang BP, Wong V. 2018. Towards 646 sustainable agriculture for the salt-affected soil. Land Degrad Develop 29: 1-6.

647 Shao YM, Zhao YY, Duan X, Wang KQ, Chen TT, Wan YP. Effects of plant roots on soil 648 preferential flow in typical forest and grassland in the dry-hot valley of Jinsha River, China. 649 Chinese Journal of Applied Ecology 31:725-734 (in Chinese).

650 Shi DM, Wang WL, Jiang GY, Peng XD, Li YX, Yu YL, Ding WB. 2016. Effects of disturbed 651 landforms on the soil water retention function during urbanization process in the Three 652 Gorges Reservoir Region, China. Catena 144: 84-93.

653 Van Noordwijk M, Schoonderbeek D, Kooistra MJ. 1993. Root-soil contact of field-grown 654 winter wheat. Geoderma 56: 277-286.

Wang YQ, Tan QW, Ma GX, Yan WH. 2012. Radar detection technology about internal cracks of mine dump. Journal of Safety Science and Technology 8: 95-100 (in Chinese).

Woerden JV. 2014. The role of fissures in the hydrology and stability of the Hollin Hill landslide. Utrecht, the Netherlands: Utrecht University.

Wu QH, Zhang JF, Lin WJ, Wang GL. 2014. Appling dyeing tracer to investigate patterns of soil water flow and quantify preferential flow in soil columns. Trans Chin Soc Agri Eng (Transactions of the CSAE) 30: 82-90 (in Chinese).

Yan JP, Chen XY, Cheng FK, Huang H, Fan TY. 2018. Effect of soil fracture priority flow on soil ammonium nitrogen transfer and soil structure in mining area. Trans Chin Soc Agri Eng (Transactions of the CSAE) 34: 120-126 (in Chinese).

Yang JH, Yu X, Yang Y, Yang ZQ. 2018. Physical simulation and theoretical evolution for ground fissures triggered by underground coal mining. Plos One 13: e0192886.

Zehe E, Graeff T, Morgner M, Bauer A, Bronstert A. 2010. Plot and field scale soil moisture dynamics and subsurface wetness control on runoff generation in a headwater in the Ore Mountains. Hydrol Earth System Sci 14: 873-889.

Zhang G, Wang R, Qian J, Zhang JM, Qian J. 2012. Effect study of cracks on behavior of soil slope under rainfall conditions. Soils Foundations 52: 634-643. 
672 Zhang YH, Zhang MX, Niu JZ, Zheng HJ. 2016a. The preferential flow of soil: A widespread 673 phenomenon in pedological perspectives. Eurasian Soil Sci 49: 661-672.

674 Zhang YX, Bi YL, Chen SL, Wang J, Han B, Feng YB. 2015. Effects of Subsidence fracture 675 caused by coal-mining on soil moisture content in semi-arid windy desert area. Environ Sci 676 Tech 38: 11-14 (in Chinese).

677 Zhang ZB, Peng XH. 2015. A review of researches on soil cracks and their impacts on 678 preferential flow. Acta Pedol Sin 52: 477-488 (in Chinese).

679 Zhang ZB, Peng XH, Wang LL, Zhao QG, Lin H. 2013. Temporal changes in shrinkage 680 behavior of two paddy soils under alternative flooding and drying cycles and its 681 consequence on percolation. Geoderma 192: 12-20.

682 Zhang ZB, Zhou H, Lin H, Peng X, 2016b.Puddling intensity, sesquioxides, and soil organic 683 carbon impacts on crack patterns of two paddy soils. Geoderma, 262, 155-164.

684 Zhou CS, Zheng XQ, Zheng LY, Wei XO. 2011. A Study on the Formation Mechanism and 685 Preventive Measures of Coal-Mining Ground Fissures in the South-West of Pingyao. Appl 686 Mechanics Materials 90-93: 1341-1344.

687 Zika M, Erb KH. 2009. The global loss of net primary production resulting from human-induced 688 soil degradation in drylands. Ecol Economics 69: 310-318. 
Figure 1

Location of the study area
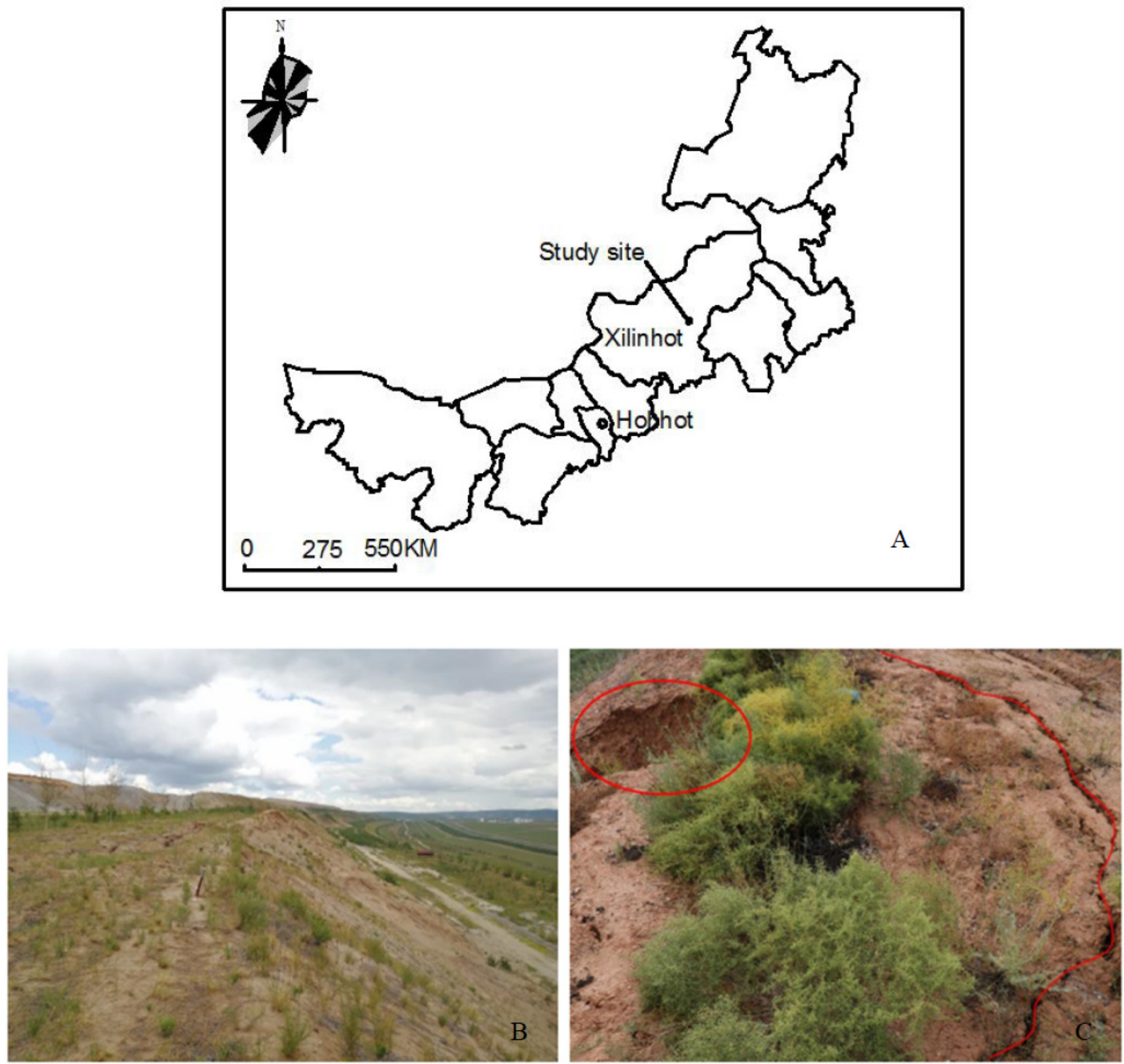
Figure 2

The dyeing test process and image processing 

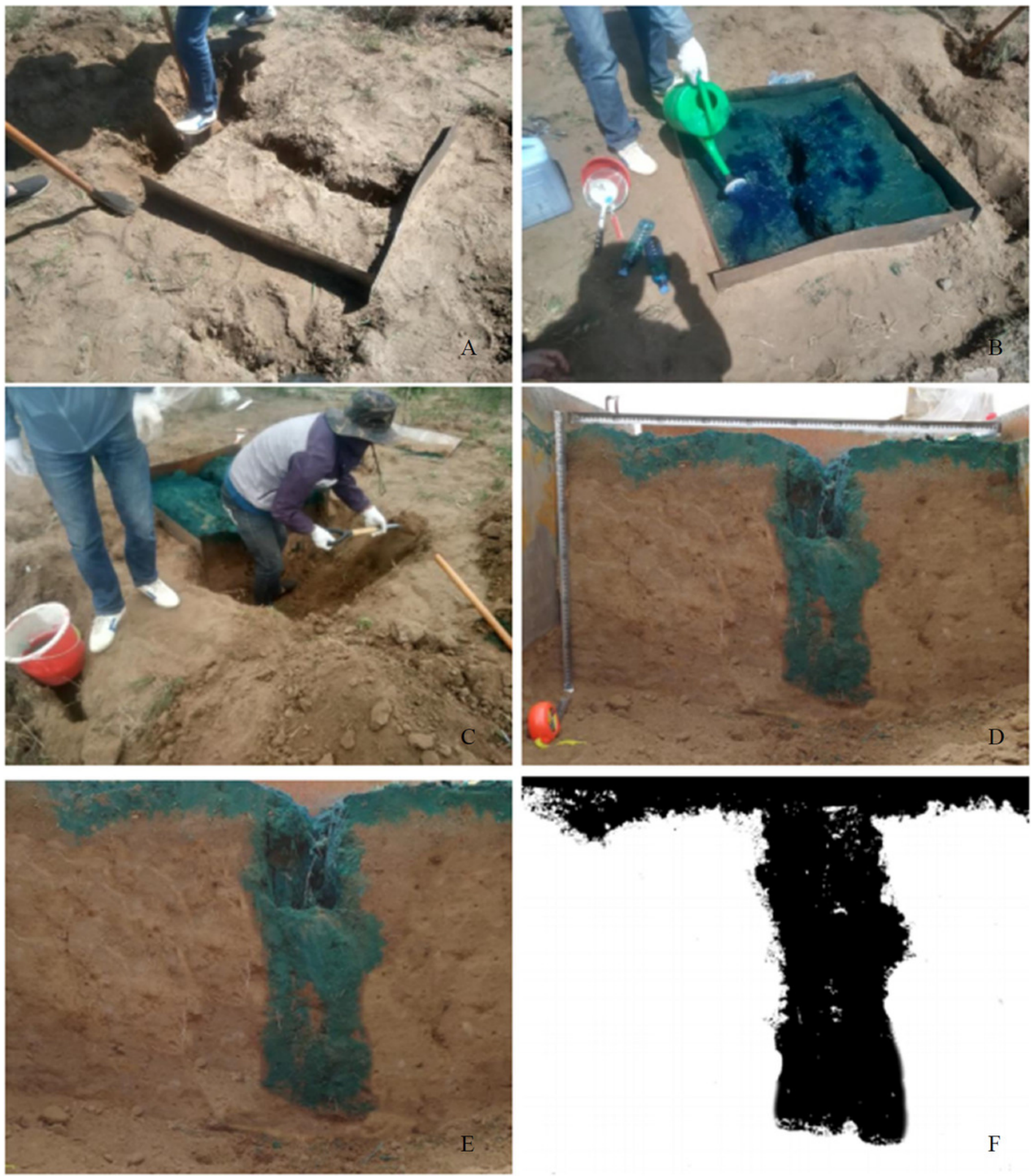
Figure 3

Change of ground fissure width with soil layer depth

(A)The width of GF I.(B) The width of GF II.(C) The width of GF III.The red lines represent soil profiles with $30 \mathrm{~cm}$, the green lines represent soilprofiles with $50 \mathrm{~cm}$, and the blue lines represent soil profiles with $70 \mathrm{~cm}$.
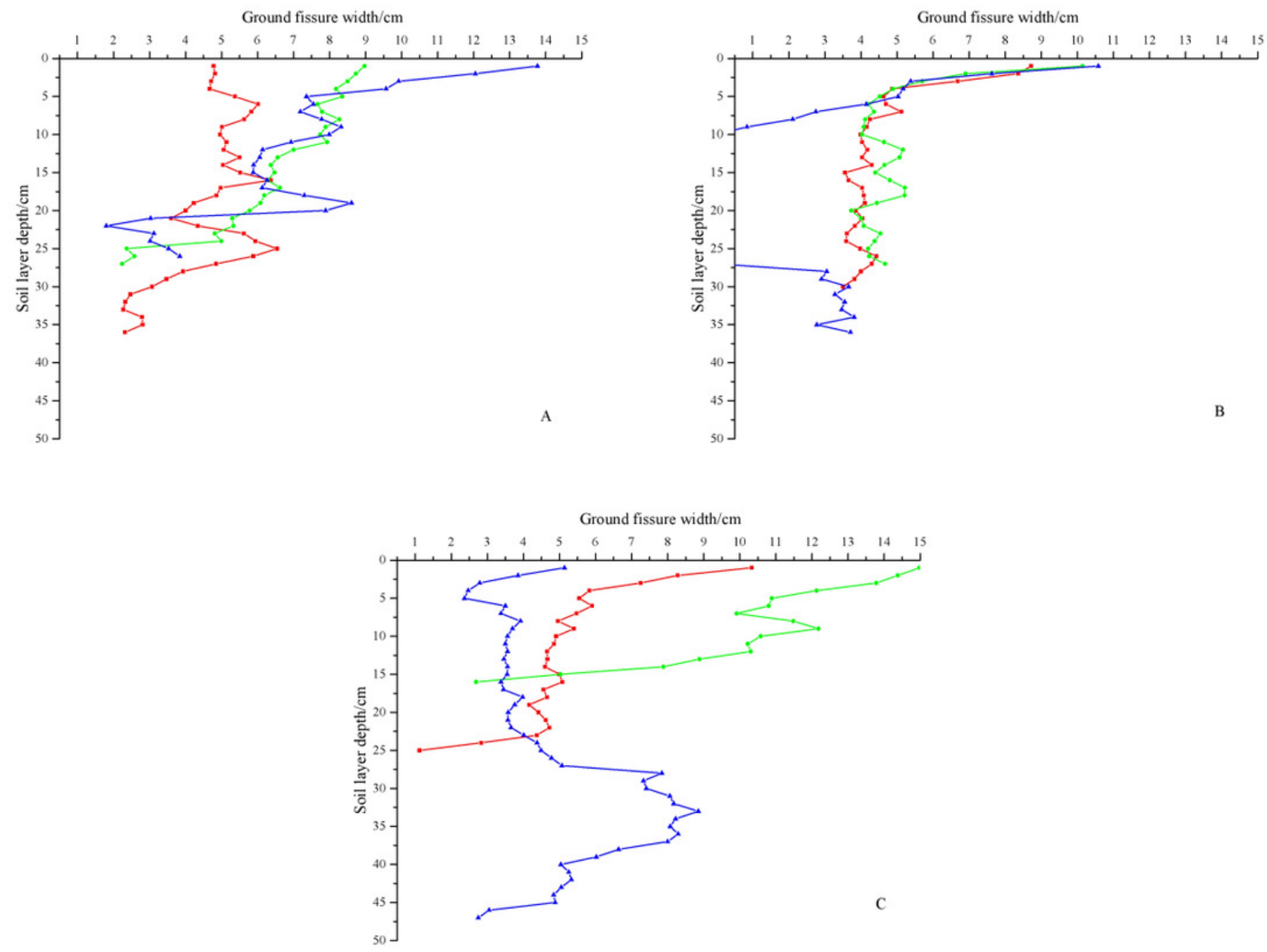
Figure 4

Ground fissure width-to-depth ratio in the dump

(A)The ground fissure width-to-depth ratio of GF I.(B) The ground fissure width-to-depth ratio of GF II.(C) The gorund fissure width-to-depth ratio of GF III.The red points represent soil profiles with $30 \mathrm{~cm}$, the green points represent soilprofiles with $50 \mathrm{~cm}$, and the blue points represent soil profiles with $70 \mathrm{~cm}$.
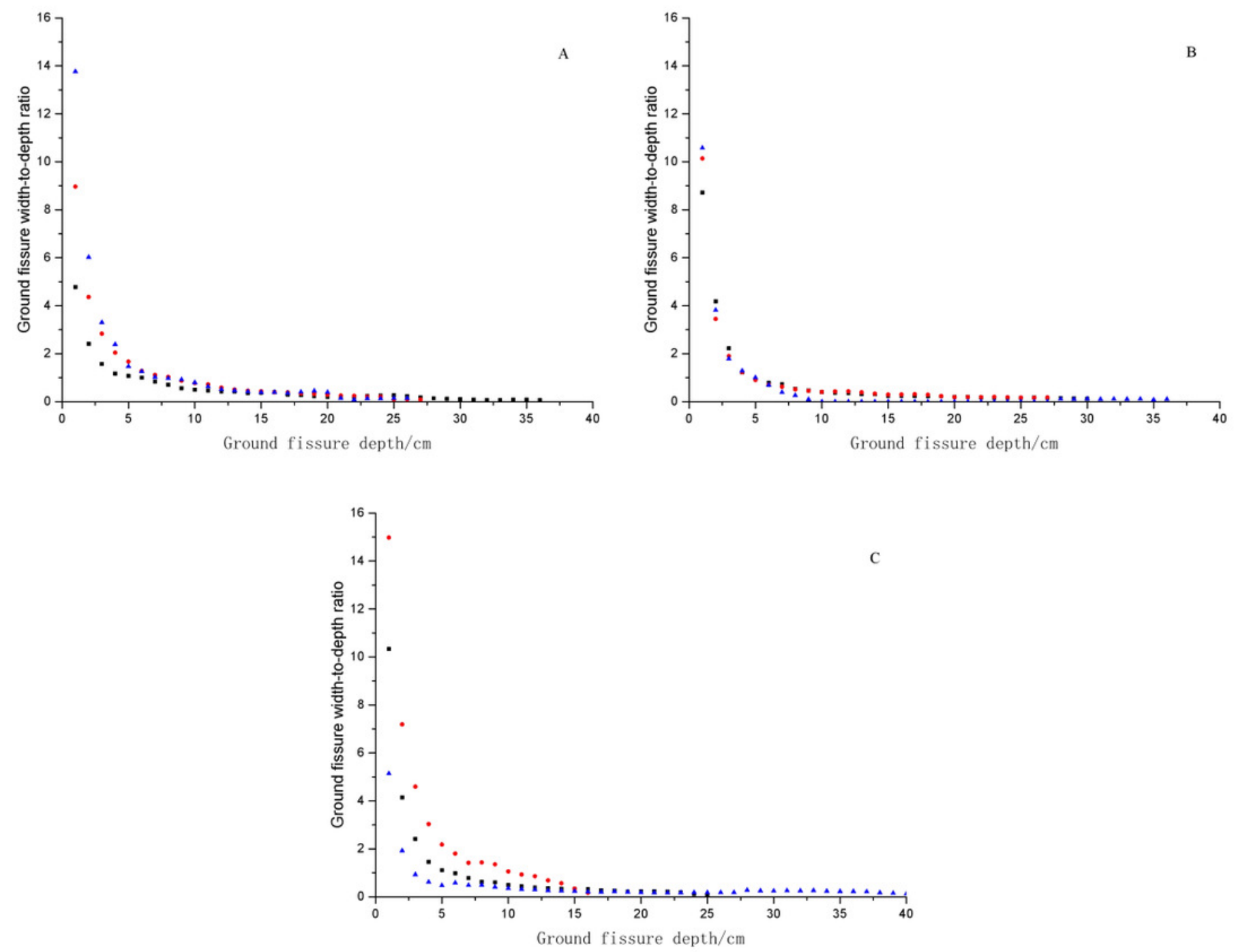
Figure 5

Vertical distribution of preferential flow

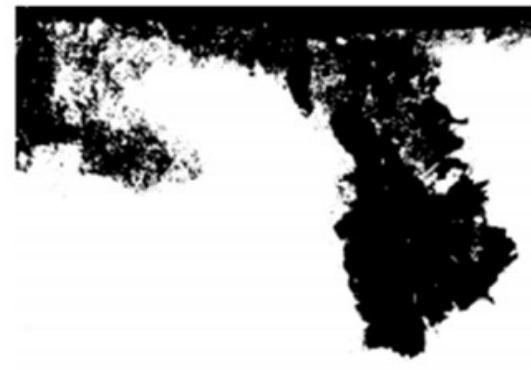

A

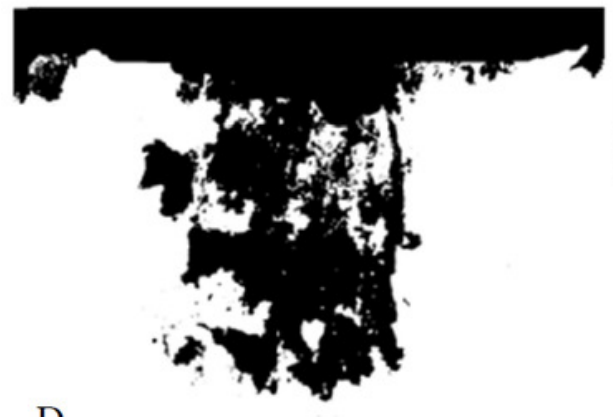

D

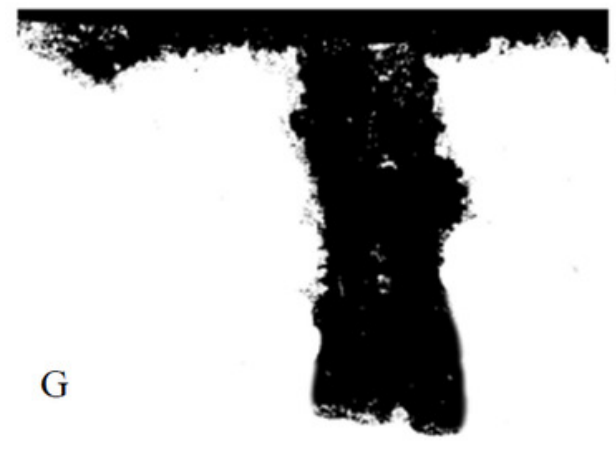

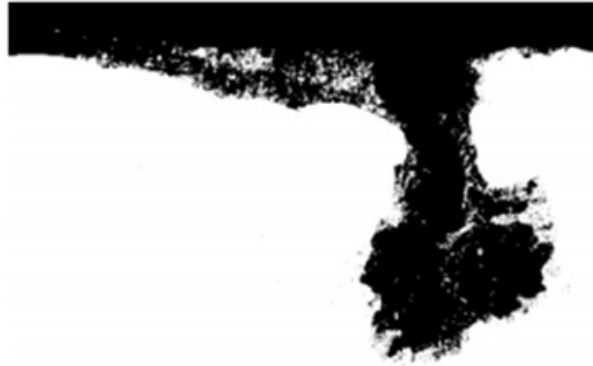

B

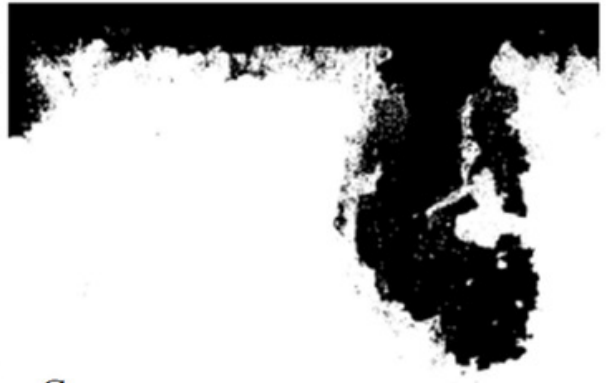

C

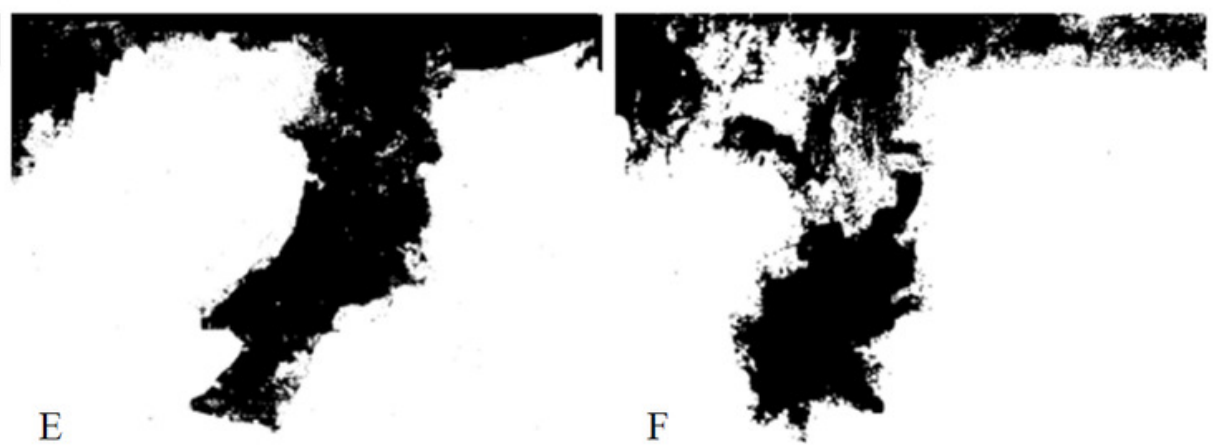

$\mathrm{H}$

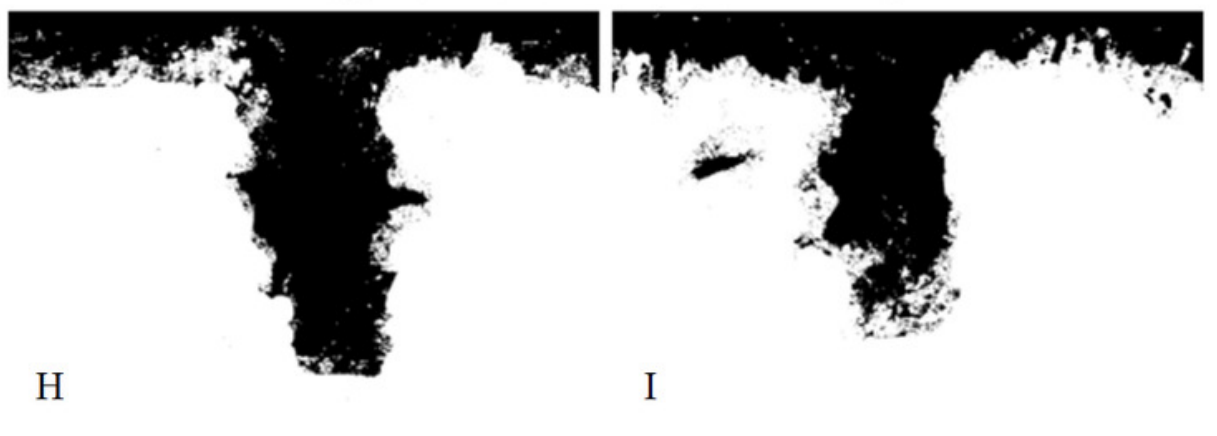


Figure 6

Stained area ratio with soil depth

(A) and (B)The stained area ratio of GF I.(C) and (D) The stained area ratio of GF II.(E) and (F) The stained area ratio of GF III.The black lines and black column represent soil profiles with $30 \mathrm{~cm}$, the pink lines and pink column represent soilprofiles with $50 \mathrm{~cm}$, and the blue lines and blue column represent soil profiles with $70 \mathrm{~cm}$. 

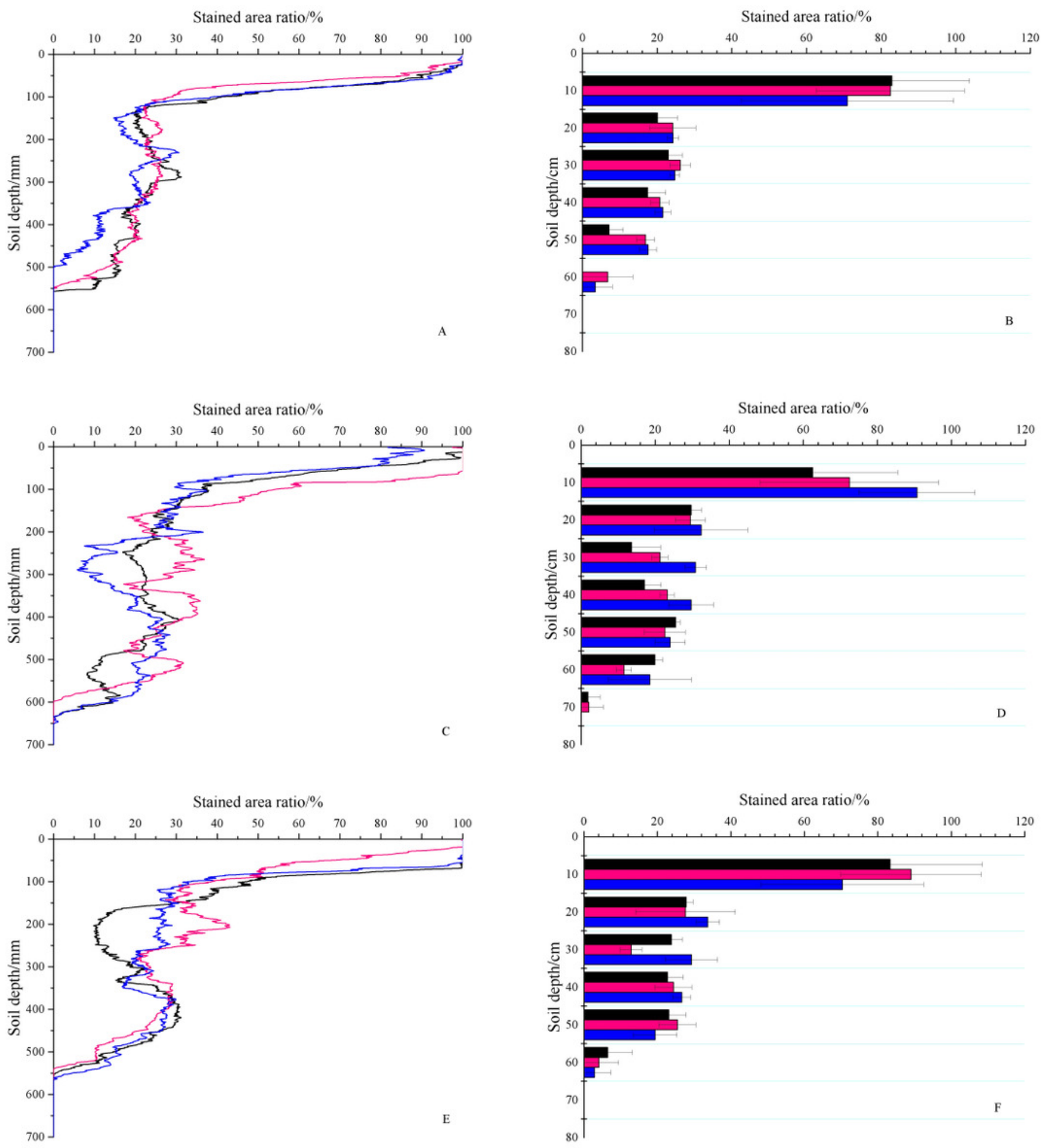
Figure 7

Distribution of stained path number

(A)The stained path number of GF I.(B) The stained path number of GF II.(C) The stained path number of GF III.The red lines represent soil profiles with $30 \mathrm{~cm}$, the green lines represent soilprofiles with $50 \mathrm{~cm}$, and the blue lines represent soil profiles with $70 \mathrm{~cm}$.
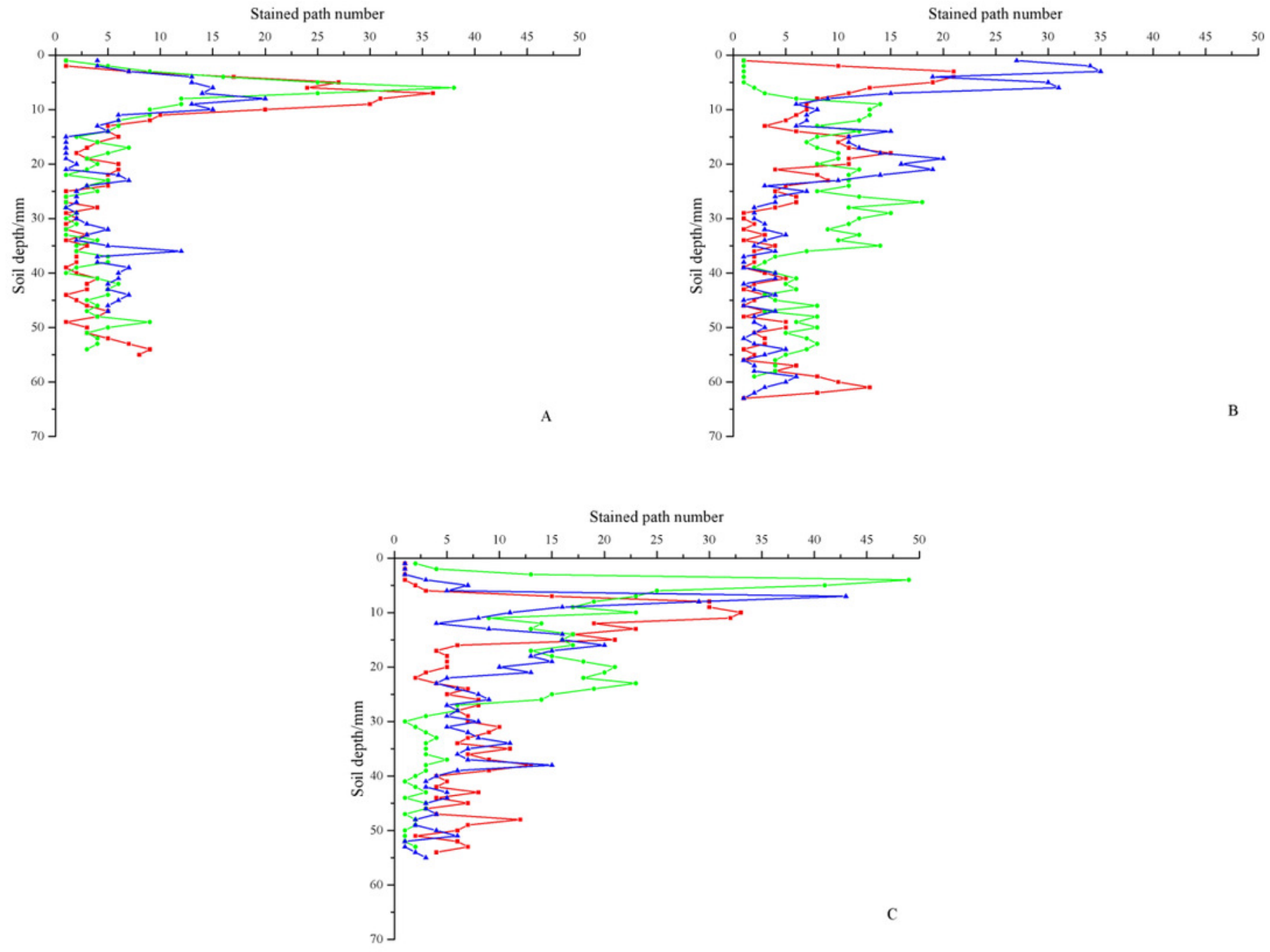
Figure 8

Characteristics of plant root in the dump

(A)The rootdensity.(B) The root weight density. (C) The root length density.(D) The root surface area density. (E) The root volume density. The red column represent GFI,the greencolumn represent GFII, and the blue column represent GF III. 

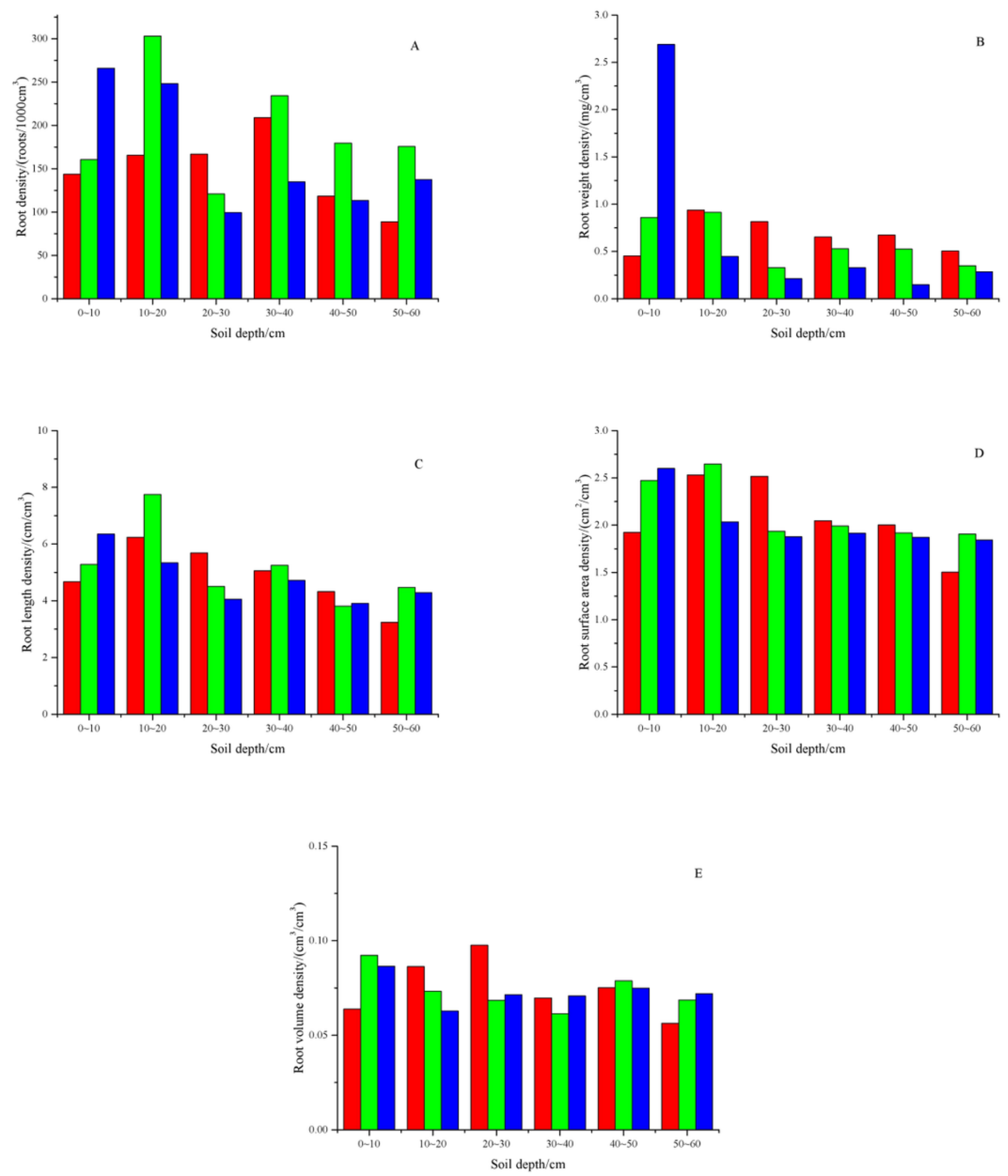
Table $\mathbf{1}$ (on next page)

Main design parameters of dump 
1 Table 1 Main design parameters of dump

\begin{tabular}{cccccccc}
\hline $\begin{array}{c}\text { Area } \\
\left(\mathrm{km}^{2}\right)\end{array}$ & $\begin{array}{c}\text { Final dumping } \\
\text { Elevation }(\mathrm{m})\end{array}$ & $\begin{array}{c}\text { Height } \\
(\mathrm{m})\end{array}$ & $\begin{array}{c}\text { Bench height } \\
(\mathrm{m})\end{array}$ & $\begin{array}{c}\text { Platform width } \\
(\mathrm{m})\end{array}$ & $\begin{array}{c}\text { Capacity } \\
\left(\mathrm{Mm}^{3}\right)\end{array}$ & $\begin{array}{c}\text { Stepped slope } \\
\text { Angle }\left({ }^{\circ}\right)\end{array}$ & $\begin{array}{c}\text { Loose } \\
\text { coefficient }\end{array}$ \\
\hline 7.60 & 1156 & 100 & 25 & 20 & 592 & 33 & 1.15 \\
\hline
\end{tabular}

2 
Table 2 (on next page)

Morphological characteristics of ground fissures in the dump 
1 Table 2 Morphological characteristics of ground fissures in the dump

\begin{tabular}{cccccccc}
\hline Plots & $\begin{array}{c}\text { Length } \\
(\mathrm{cm})\end{array}$ & $\begin{array}{c}\text { Width } \\
(\mathrm{cm})\end{array}$ & $\begin{array}{c}\text { Depth } \\
(\mathrm{cm})\end{array}$ & $\begin{array}{c}\text { Perimeter } \\
(\mathrm{cm})\end{array}$ & $\begin{array}{c}\text { Area } \\
\left(\mathrm{cm}^{2}\right)\end{array}$ & $\begin{array}{c}\text { Length density } \\
\left(\mathrm{cm} \mathrm{cm}^{-2}\right)\end{array}$ & $\begin{array}{c}\text { Area density } \\
(\%)\end{array}$ \\
\hline GF I & 120.83 & $9.85 \pm 3.48 \mathrm{a}$ & $29 \pm 6.08 \mathrm{a}$ & 287.65 & $983.92 \mathrm{a}$ & 0.012 & $9.84 \mathrm{a}$ \\
GF II & 109.90 & $2.86 \pm 0.84 \mathrm{c}$ & $30.67 \pm 5.03 \mathrm{a}$ & 230.65 & $286.47 \mathrm{c}$ & 0.011 & $2.86 \mathrm{c}$ \\
GF III & 104.84 & $5.77 \pm 2.76 \mathrm{~b}$ & $28.67 \pm 15.82 \mathrm{a}$ & 228.58 & $576.70 \mathrm{~b}$ & 0.010 & $5.76 \mathrm{~b}$ \\
\hline
\end{tabular}

2 Note: Values aremean \pm standard deviation. The width and depth were an average value of multiple

3 measurement points. Different lowercase letters indicate significant differences between different plots

$4 \quad(\mathrm{P}<0.05)$. 


\section{Table 3(on next page)}

Stained path number and width with different soil depth 
1 Table 3 Stained path number and width with different soil depth

\begin{tabular}{|c|c|c|c|c|c|c|c|c|c|c|}
\hline \multirow{2}{*}{$\begin{array}{l}\text { Staine } \\
\text { d path }\end{array}$} & \multirow{2}{*}{$\begin{array}{l}\text { Soil } \\
\text { depth } \\
(\mathrm{cm})\end{array}$} & \multicolumn{3}{|c|}{ GF I } & \multicolumn{3}{|c|}{ GF II } & \multicolumn{3}{|c|}{ GFIII } \\
\hline & & $30 \mathrm{~cm}$ & $50 \mathrm{~cm}$ & $70 \mathrm{~cm}$ & $30 \mathrm{~cm}$ & $50 \mathrm{~cm}$ & $70 \mathrm{~cm}$ & $30 \mathrm{~cm}$ & $50 \mathrm{~cm}$ & $70 \mathrm{~cm}$ \\
\hline \multirow{7}{*}{$\begin{array}{c}\text { Numb } \\
\text { er }\end{array}$} & $0-10$ & $4 \sim 20$ & $1 \sim 36$ & $1 \sim 38$ & $6 \sim 35$ & $1 \sim 21$ & $1 \sim 14$ & $1 \sim 43$ & $1 \sim 33$ & $2 \sim 49$ \\
\hline & $10-20$ & $1 \sim 6$ & $2 \sim 10$ & $2 \sim 9$ & $6 \sim 20$ & $3 \sim 15$ & $7 \sim 13$ & $4 \sim 20$ & $4 \sim 32$ & $9 \sim 21$ \\
\hline & $20-30$ & $1 \sim 7$ & $1 \sim 6$ & $1 \sim 5$ & $2 \sim 19$ & $1 \sim 9$ & $8 \sim 18$ & $4 \sim 13$ & $2 \sim 8$ & $1 \sim 23$ \\
\hline & $30-40$ & $2 \sim 12$ & $1 \sim 3$ & $1 \sim 5$ & $1 \sim 5$ & $1 \sim 4$ & $2 \sim 14$ & $4 \sim 15$ & $4 \sim 13$ & $2 \sim 5$ \\
\hline & $40-50$ & $0 \sim 7$ & $1 \sim 5$ & $3 \sim 9$ & $1 \sim 4$ & $1 \sim 5$ & $3 \sim 8$ & $2 \sim 5$ & $3 \sim 12$ & $1 \sim 3$ \\
\hline & $50-60$ & 0 & $0 \sim 9$ & $0 \sim 4$ & $1 \sim 6$ & $1 \sim 10$ & $0 \sim 8$ & $0 \sim 6$ & $0 \sim 7$ & $0 \sim 2$ \\
\hline & $60-70$ & 0 & 0 & 0 & $0 \sim 3$ & $0 \sim 13$ & 0 & 0 & 0 & 0 \\
\hline \multirow{7}{*}{$\begin{array}{l}\text { Width } \\
\text { (cm) }\end{array}$} & $0-10$ & $30.5 \sim 89$ & $22.8 \sim 90$ & $21.5 \sim 90$ & $\begin{array}{c}21.4 \sim 67 \\
.3\end{array}$ & $\begin{array}{c}28.9 \sim 89 \\
.3\end{array}$ & $44.6 \sim 90$ & 21.9 90 & 28.2 90 & $26 \sim 89.8$ \\
\hline & $10-20$ & $12.5 \sim 21$ & $\begin{array}{c}14.8 \sim 21 \\
.8\end{array}$ & 17.9 22 & $\begin{array}{c}14.9 \sim 26 \\
.3\end{array}$ & $\begin{array}{c}18.2 \sim 31 \\
.7\end{array}$ & $12.2 \sim 41$ & $18 \sim 20.8$ & $\begin{array}{c}9.1 \sim 26 . \\
7\end{array}$ & $\begin{array}{c}17.1 \sim 29 \\
.1\end{array}$ \\
\hline & $20-30$ & $\begin{array}{c}15.8 \sim 23 \\
.4\end{array}$ & $\begin{array}{c}17.9 \sim 26 \\
.6\end{array}$ & $\begin{array}{c}18.3 \sim 22 \\
.8\end{array}$ & $\begin{array}{c}2.8 \sim 19 \\
1\end{array}$ & $13.4 \sim 20$ & $\begin{array}{c}15.2 \sim 24 \\
.4\end{array}$ & $\begin{array}{c}13.8 \sim 21 \\
.1\end{array}$ & $\begin{array}{c}7.7 \sim 12 . \\
3\end{array}$ & $13.2 \sim 31$ \\
\hline & $30-40$ & $\begin{array}{c}6.7 \sim 18 . \\
5\end{array}$ & $\begin{array}{c}14.3 \sim 20 \\
.5\end{array}$ & $\begin{array}{c}15.4 \sim 21 \\
.2\end{array}$ & $\begin{array}{c}5.3 \sim 18 \\
9\end{array}$ & $17.4 \sim 38$ & $\begin{array}{c}11.1 \sim 30 \\
.6\end{array}$ & $\begin{array}{c}11.9 \sim 23 \\
.2\end{array}$ & $10 \sim 25.8$ & $\begin{array}{c}19.6 \sim 25 \\
.2\end{array}$ \\
\hline & $40-50$ & $0 \sim 6.2$ & $11.1 \sim 17$ & $15.3 \sim 27$ & $\begin{array}{c}19.8 \sim 23 \\
.9\end{array}$ & $\begin{array}{c}8.5 \sim 24 . \\
1\end{array}$ & $\begin{array}{c}12.8 \sim 24 \\
.7\end{array}$ & $\begin{array}{c}12.3 \sim 24 \\
.1\end{array}$ & $\begin{array}{c}11.9 \sim 25 \\
.9\end{array}$ & $\begin{array}{c}8.7 \sim 22 . \\
9\end{array}$ \\
\hline & $50-60$ & 0 & $0 \sim 12.1$ & $0 \sim 25.7$ & $10 \sim 17.7$ & $6.8 \sim 9.5$ & $0 \sim 25.3$ & $0 \sim 12.3$ & $0 \sim 8.7$ & $0 \sim 9.1$ \\
\hline & $60-70$ & 0 & 0 & 0 & $0 \sim 5.2$ & $0 \sim 4.8$ & 0 & 0 & 0 & 0 \\
\hline
\end{tabular}




\section{Table 4 (on next page)}

Relationship between soil preferential flow and ground fissure width and width-to-depth ratio 
1 Table 4 Relationship between soil preferential flow and ground fissure width and width-to-depth ratio

\begin{tabular}{cccccc}
\hline Index & $S A R$ & $S P N$ & $S P W$ & $G F W$ & $G F W R$ \\
\hline$S A R$ & 1.000 & $0.336^{* *}$ & $0.947^{* *}$ & $0.309^{* *}$ & $0.681^{* *}$ \\
$S P N$ & & 1.000 & $0.168^{* *}$ & -0.107 & $0.123^{*}$ \\
$S P W$ & & 1.000 & $0.346^{* *}$ & $0.649^{* *}$ \\
GFW & & & 1.000 & $0.746^{* *}$ \\
GFWR & & & & 1.000 \\
\hline
\end{tabular}

2 Note: ${ }^{*} \mathrm{P}<0.01,{ }^{*} \mathrm{P}<0.05, \mathrm{n}=270 . S A R$ stained area ratio, $S P N$ stained path number, $S P W$ stained path width,

$3 G F W$ ground fissure width, and GFWR ground fissure width-to-depth ratio. 


\section{Table 5 (on next page)}

Soil physiochemical properties in the dump 
1 Table 5 Soil physiochemical properties in the dump

\begin{tabular}{|c|c|c|c|c|c|c|c|c|c|c|}
\hline \multirow{2}{*}{ Plots } & \multirow{2}{*}{$\begin{array}{l}\text { Soil depth } \\
(\mathrm{cm})\end{array}$} & \multirow{2}{*}{$\begin{array}{l}S W C \\
(\%)\end{array}$} & \multirow{2}{*}{$\begin{array}{c}S B D \\
\left(\mathrm{~g} \mathrm{~cm}^{-3}\right)\end{array}$} & \multirow{2}{*}{$\begin{array}{l}C P \\
(\%)\end{array}$} & \multirow{2}{*}{$\begin{array}{l}N P C \\
(\%)\end{array}$} & \multirow{2}{*}{$\begin{array}{c}S H C \\
\left(\mathrm{~mm} \mathrm{~min}^{-1}\right)\end{array}$} & \multirow{2}{*}{$\begin{array}{c}S O M \\
\left(\mathrm{~g} \mathrm{~kg}^{-1}\right)\end{array}$} & \multicolumn{3}{|c|}{ Soil mechanical composition (\%) } \\
\hline & & & & & & & & Sand & Silt & Clay \\
\hline \multirow{7}{*}{ GF I } & $0-10$ & 6.03 & 1.30 & 36.70 & 14.27 & 1.10 & 32.66 & 77.21 & 12.25 & 11.54 \\
\hline & $10-20$ & 6.36 & 1.41 & 29.28 & 18.11 & 0.94 & 26.36 & 74.68 & 16.54 & 8.78 \\
\hline & $20-30$ & 5.09 & 1.41 & 30.42 & 16.95 & 0.87 & 21.47 & 76.58 & 10.25 & 13.17 \\
\hline & $30-40$ & 4.26 & 1.36 & 33.17 & 15.76 & 0.90 & 26.97 & 70.24 & 16.38 & 13.38 \\
\hline & $40-50$ & 4.31 & 1.34 & 32.72 & 17.17 & 0.73 & 20.64 & 71.53 & 13.84 & 14.63 \\
\hline & $50-60$ & 4.14 & 1.34 & 32.70 & 17.14 & 0.42 & 18.54 & 71.48 & 14.53 & 13.99 \\
\hline & $0-60$ & $5.03 \mathrm{a}$ & $1.36 \mathrm{a}$ & $32.50 \mathrm{a}$ & $16.57 \mathrm{a}$ & $0.83 \mathrm{a}$ & $24.44 \mathrm{a}$ & $73.62 \mathrm{a}$ & $13.97 \mathrm{a}$ & $12.58 \mathrm{a}$ \\
\hline \multirow{7}{*}{ GF II } & $0-10$ & 7.16 & 1.31 & 33.41 & 17.35 & 1.18 & 22.82 & 78.62 & 12.05 & 9.33 \\
\hline & $10-20$ & 4.71 & 1.45 & 19.88 & 26.14 & 1.05 & 17.51 & 75.64 & 17.64 & 6.72 \\
\hline & $20-30$ & 4.30 & 1.31 & 34.49 & 16.27 & 0.73 & 18.56 & 75.34 & 16.37 & 8.29 \\
\hline & $30-40$ & 4.29 & 1.25 & 36.51 & 16.19 & 0.40 & 22.74 & 72.18 & 15.38 & 12.44 \\
\hline & $40-50$ & 4.68 & 1.22 & 38.29 & 15.35 & 0.27 & 23.82 & 70.39 & 16.08 & 13.53 \\
\hline & $50-60$ & 5.00 & 1.23 & 39.30 & 14.20 & 0.18 & 20.87 & 72.35 & 14.38 & 13.27 \\
\hline & $0-60$ & $5.02 \mathrm{a}$ & $1.30 \mathrm{a}$ & $33.65 \mathrm{a}$ & $17.58 \mathrm{a}$ & $0.64 \mathrm{a}$ & $21.05 \mathrm{a}$ & $74.09 \mathrm{a}$ & $15.32 \mathrm{a}$ & $10.60 \mathrm{a}$ \\
\hline \multirow{7}{*}{ GF III } & $0-10$ & 6.04 & 1.39 & 29.55 & 18.40 & 1.19 & 29.77 & 74.35 & 15.34 & 10.31 \\
\hline & $10-20$ & 7.42 & 1.42 & 29.12 & 17.97 & 1.06 & 28.67 & 70.84 & 14.57 & 14.59 \\
\hline & $20-30$ & 4.89 & 1.43 & 27.91 & 19.03 & 1.25 & 25.62 & 69.58 & 16.13 & 14.29 \\
\hline & $30-40$ & 5.99 & 1.26 & 37.18 & 15.07 & 0.84 & 21.65 & 74.25 & 14.47 & 11.28 \\
\hline & $40-50$ & 6.05 & 1.31 & 36.19 & 14.39 & 0.40 & 24.04 & 73.35 & 14.28 & 12.37 \\
\hline & $50-60$ & 6.02 & 1.29 & 36.10 & 15.17 & 0.22 & 13.03 & 71.57 & 14.58 & 13.85 \\
\hline & $0-60$ & $6.07 \mathrm{a}$ & $1.35 \mathrm{a}$ & $32.68 \mathrm{a}$ & $16.67 \mathrm{a}$ & $0.83 a$ & $23.80 \mathrm{a}$ & $72.32 \mathrm{a}$ & $14.90 \mathrm{a}$ & $12.78 \mathrm{a}$ \\
\hline
\end{tabular}

2 Note: The data in the table is the average. Different lowercase letters indicate significant differences among the

3 three ground fissures $(P<0.05)$. $S W C$ soil water content, $S B D$ soil bulk density, $C P$ capillary porosity, $N C P$

4 non-capillary porosity, $S H C$ saturated hydraulic conductivity, $S O M$ soil organic matter, sand (0.02-2 mm), silt

$5 \quad(0.02-0.002 \mathrm{~mm})$, clay $(<0.002 \mathrm{~mm})$. 
Table 6(on next page)

Relationship between soil preferential flow and soil physicochemical properties 
1 Table 6 Relationship between soil preferential flow and soil physicochemical properties

\begin{tabular}{|c|c|c|c|c|c|c|c|c|c|c|c|c|}
\hline $\begin{array}{c}\text { Inde } \\
\mathrm{x}\end{array}$ & $S A R$ & $S P N$ & $S P W$ & $S W C$ & $S B D$ & $C P$ & $N C P$ & $S H C$ & $S O M$ & Sand & Silt & Clay \\
\hline$S A R$ & $\begin{array}{c}1.00 \\
0\end{array}$ & $\begin{array}{c}0.732^{*} \\
*\end{array}$ & $\begin{array}{c}0.981^{*} \\
*\end{array}$ & $\begin{array}{c}- \\
0.548^{*}\end{array}$ & $\begin{array}{c}- \\
0.192\end{array}$ & -0.152 & 0.255 & $0.632^{* *}$ & $\begin{array}{c}0.527 \\
*\end{array}$ & $\begin{array}{c}0.511 \\
*\end{array}$ & $\begin{array}{c}- \\
0.007\end{array}$ & $-0.527^{*}$ \\
\hline$S P N$ & & 1.000 & $\begin{array}{c}0.647^{*} \\
*\end{array}$ & -0.461 & $\begin{array}{c}- \\
0.277\end{array}$ & -0.257 & 0.383 & $0.746^{* *}$ & $\begin{array}{c}0.507 \\
*\end{array}$ & 0.324 & 0.199 & -0.465 \\
\hline$S P W$ & & & 1.000 & -0.463 & $\begin{array}{c}- \\
0.176\end{array}$ & -0.129 & 0.222 & $0.588^{*}$ & $\begin{array}{c}0.544 \\
*\end{array}$ & $\begin{array}{c}0.487 \\
*\end{array}$ & $\begin{array}{c}- \\
0.009\end{array}$ & $-0.505^{*}$ \\
\hline$S W C$ & & & & 1.000 & 0.154 & -0.121 & 0.082 & 0.384 & 0.451 & 0.378 & $\begin{array}{c}- \\
0.335\end{array}$ & -0.201 \\
\hline$S B D$ & & & & & 1.000 & $\begin{array}{c}- \\
0.969^{* *}\end{array}$ & $0.815^{* *}$ & $\begin{array}{c}- \\
0.688^{* *}\end{array}$ & 0.168 & 0.059 & 0.334 & -0.092 \\
\hline$C P$ & & & & & & 1.000 & $\begin{array}{c}- \\
0.909^{* *}\end{array}$ & $\begin{array}{c}- \\
0.648^{* *}\end{array}$ & $\begin{array}{c}- \\
0.079\end{array}$ & $\begin{array}{c}- \\
0.018\end{array}$ & $\begin{array}{c}- \\
0.356\end{array}$ & 0.049 \\
\hline$N C P$ & & & & & & & 1.000 & $0.654^{* *}$ & 0.053 & 0.050 & 0.439 & -0.162 \\
\hline SHC & & & & & & & & 1.000 & $\begin{array}{c}0.567 \\
*\end{array}$ & 0.199 & 0.193 & -0.293 \\
\hline$S O M$ & & & & & & & & & 1.000 & 0.140 & 0.146 & 0.073 \\
\hline Sand & & & & & & & & & & 1.000 & $\begin{array}{c}- \\
0.237\end{array}$ & $\begin{array}{c}- \\
0.777^{* *}\end{array}$ \\
\hline Silt & & & & & & & & & & & 1.000 & -0.337 \\
\hline Clay & & & & & & & & & & & & 1.000 \\
\hline
\end{tabular}

2 Note: $* * \mathrm{P}<0.01, * \mathrm{P}<0.05, \mathrm{n}=18$. 
Table 7 (on next page)

Relationship between soil preferential flow and plant root 
1 Table 7 Relationship between soil preferential flow and plant root

\begin{tabular}{ccccccccc}
\hline Index & $S A R$ & $S P N$ & $S P W$ & $R D$ & $R W D$ & $R L D$ & $R S A D$ & $R V D$ \\
\hline$S A R$ & 1.000 & $0.732^{* *}$ & $0.981^{* *}$ & $0.550^{*}$ & 0.426 & $0.664^{* *}$ & $0.612^{* *}$ & 0.338 \\
$S P N$ & & 1.000 & $0.647^{* *}$ & 0.280 & 0.203 & $0.505^{*}$ & 0.445 & 0.017 \\
$S P W$ & & & 1.000 & $0.589^{*}$ & $0.482^{*}$ & $0.639^{* *}$ & $0.626^{* *}$ & 0.343 \\
$R D$ & & & & 1.000 & $0.573^{*}$ & $0.717^{* *}$ & $0.692^{* *}$ & 0.117 \\
$R W D$ & & & & & 1.000 & $0.692^{* *}$ & $0.853^{* *}$ & 0.467 \\
$R L D$ & & & & & & 1.000 & $0.903^{* *}$ & 0.307 \\
$R S A D$ & & & & & & & 1.000 & $0.472^{*}$ \\
$R V D$ & & & & & & & & 1.000 \\
\hline
\end{tabular}

2 Note: $* * \mathrm{P}<0.01, * \mathrm{P}<0.05, \mathrm{n}=18$. $R D$ root density, $R W D$ root weight density, $R L D$ root length density, $R S A D$

3 root surface area density, $R V D$ root volume density. 